El delito de receptación aduanera

y la normativización del dolo

María Magdalena Ossandón Widow

páginas 49 - 85

\title{
EL DELITO DE RECEPTACIÓN ADUANERA Y LA NORMATIVIZACIÓN DEL DOLO*
}

María Magdalena Ossandón Widow*

RESUMEN La referencia a un deber de presumir el origen delictivo de las mercancías en el delito de receptación aduanera puede ser objeto de diversas interpretaciones. Luego de analizar las alternativas tradicionales, se plantea una nueva perspectiva: concebirlo como expresión de la normativización del dolo. Esta posibilidad surge dentro del proceso general de normativización del sistema penal y, en particular, por los problemas que plantea el concepto psicológico tradicional. El significado atributivo que reviste el dolo, desde este punto de vista, repercute en diversas cuestiones de orden práctico, las que son descritas en el contexto del delito de receptación aduanera.

\section{PALABRAS CLAVE}

receptación — receptación aduanera — prueba del dolo — presunciones — concepto psicológico de dolo — concepto normativo de dolo - competencia — ignorancia deliberada.

\section{ABSTRACT}

The reference to having presumed the criminal origin of the merchandise in the crime of customs receiving can be object under diverse interpretations. After to analyze the

Trabajo escrito en el marco del proyecto "Protección penal del patrimonio público: estudio dogmático y crítico", Proyecto Fondecyt 1060816, 20062008. Artículo recepcionado el 10 de marzo de 2008 y aprobada su publicación el 10 de abril de 2008.

Profesora de Derecho Penal, Pontificia Universidad Católica de Valparaíso. Correo electrónico: magdalenaos-sandon@yahoo. es

Revista Ius et Praxis - año 14 - n 149

Magdalena Ossandon Widow

traditional options, a new perspective could be considered, namely: to conceive it like expression of the wilful misconduct's normativisation. This possibility arises within the general process of the criminal system's normativisation and, in special, by the problems that raise the traditional psychological concept. The attributive meaning of that has the wilful misconduct /malice. From this point of view, it has repercussions in multiple practical application and questions, those that are described in the context of the crime of customs receiving.

\section{KEYWORDS}

customs receiving — wilful misconduct's evidence — presumption — psychological concept of wilful misconduct — normative concept of wilful misconduct — "competencia" — deliberate ignorance.

\section{Nociones generales}

En la Ordenanza de Aduanas se tipifican una serie de ilícitos penales con los que se pretende resguardar el correcto desempeño de la función aduanera, en tanto actividad de control sobre el tráfico internacional de mercancías. Dicha función se concreta en un doble objetivo ${ }^{1}$ : la percepción tributaria y la fiscalización de las prohibiciones y restricciones que la ley establece respecto de ese tráfico². De este modo, es posible afirmar que los delitos aduaneros, en general, tienen como fundamento la necesidad de proteger tanto el patrimonio público como los valores que sirven de base a aquellas limitaciones, entre los que se cuentan la salud pública, el medio ambiente, la seguridad pública y el patrimonio 
histórico y cultural ${ }^{3}$.

Así lo reconocen varias disposiciones, entre ellas, el artículo I ${ }^{0}$ de la Ley Orgánica del Servicio de Aduanas y el artículo 152 letra b) de la Ordenanza de Aduanas.

Arocena, G., Delitos aduaneros, Edit. Mediterránea, Córdoba, 2004, pp. 60-61.

El tema del bien jurídico protegido por los delitos aduaneros dista de ser pacífico. Las posiciones van desde quienes vinculan el interés tutelado por estas figuras derechamente con la función o con la potestad aduanera o, más en concreto, con el efectivo ejercicio de la función de control; quienes lo reducen ai patrimonio público en un sentido funcional, es decir, como el mecanismo que permite al Estado realizar su labor para satisfacer las necesidades públicas; quienes lo amplían al orden público económico, por sus repercusiones en la economía nacional, pues lesionan la competencia leal entre los diferentes agentes, las transacciones comerciales, el comercio internacional, el régimen cambiario, la política laboral, la industria nacional, etc.; $y$, por último, quienes sostienen que los delitos aduaneros tienen un carácter pluriofensivo, pues cada figura delictiva obedece a su propio fundamento y tiene un sentido de protección específico. Sobre las diversas posiciones, vid., portados, Mayer Lux, L., "El patrimonio del Estado como objeto de protección penal", en Revista de Derecho Pontificia Universidad Católica de Valparaíso, XXK, 2007, passim. En Chile,

tradicionalmente se ha inclinado por considerar la potestad aduanera como bien jurídico protegido, Etcheberry, A., Derecho penal. Parte especial, III, Edit. Jurídica de Chile, Santiago, 1998, p. 445. Rodríguez Collao admitía con reservas esta tesis enBases para una reforma sistemática del libro III de la Ordenanza de Aduanas, informe inédito, 1997, pp. 24-25; para posteriormente considerar que estos delitos tienen en

50 Revista Ius et Praxis - año $14-n^{\circ} 1$

El delito de receptación aduanera y la normativización del dolo

Entre todos estos delitos, nos detendremos ahora en el estudio de lo que se conoce como receptación aduanera, tipificado en el art. 182 incisos primero y segundo de la Ordenanza de Aduana, que dispone lo siguiente:

Artículo 182.- Las penas establecidas por los delitos de contrabando o fraude se aplicarán también a las personas que adquieran, reciban o escondan mercancías, sabiendo o debiendo presumir que han sido o son objeto de los delitos a que se refiere este Título.

Se presumirá dicho conocimiento de parte de las personas mencionadas por el solo hecho de encontrarse en su poder las mercancías objeto del fraude o contrabando.

Esta disposición contiene una especie de encubrimiento, pues describe un comportamiento posterior al contrabando que consiste en adquirir, recibir o esconder las mercancías objeto de ese delito. Las dos primeras conductas son constitutivas de un aprovechamiento real o receptación, mientras que la tercera puede ser calificada de favorecimiento real.

Pese a la forma como se regula el encubrimiento en nuestro Código penal, en general como una modalidad de participación en el hecho principal, este ilícito está configurado en la OA de modo autónomo. En este sentido, su regulación guarda mayor consonancia con la tendencia comparada y con la opinión doctrinal que sostiene que después de consumado un delito no es posible tener participación en él ${ }^{4}$. Más aún, no puede afirmarse que estas conductas aten-ten contra los intereses patrimoniales del Estado ni contra los valores que resguarda la potestad aduanera del mismo modo que como ocurre en el delito previo, porque esos bienes jurídicos ya se vieron lesionados por aquél, y esa lesión no es incrementada — $\mathrm{O}$ al menos no de modo tan relevante- con el comportamiento posterior.

Así, de modo mayoritario se entiende que el encubrimiento es un ilícito independiente que atenta, fundamentalmente, contra la Administración de Justicia. Pero incluso desde esta perspectiva, no se le puede desconectar absolutamente del delito que le antecede, pues bien puede afirmarse que el encubrimiento (y la receptación como una de sus formas específicas) protege el bien jurídico del delito previo "en la medida en que entonces se tutela", es decir, a través de la Administración de Justicia ${ }^{5}$.

realidad un carácter pluriofensivo, en AAW, Estudio de una nueva regulación del sistema sancionatorio contenido en la Ordenanza de aduanas. Propuesta de reforma de las normas sancionatorias y procedimentales aduaneras, Segundo informe, 2007, inédito, p. 13. En cambio, postula que el bien jurídico tiene una naturaleza fundamentalmente patrimonial, Guzmán Dálbora, J. L., Contrabando y fraude aduanero, Edeval, Valparaíso, 1998, pp. 26-30. En cualquier caso, resulta evidente que no puede tener como sujeto activo al autor del delito encubierto, pues para él se configura como un hecho posterior copenado impune, absorbido por el hecho principal. Sánchez-Ostiz Gutiérrez, R, El encubrimiento como delito, Tirant lo Blanch, Valencia, 1998, p. 57 y ss.

Revista Ius et Praxis - año 14 - n 151

Magdalena Ossandon Widow

En el caso particular de la receptación, el fundamento del castigo resulta más controvertido porque, de algún modo, la conexión con el hecho previo parece ser más intensa. En esta línea, la doctrina ha ofrecido diversas explicaciones sobre el injusto de este delito 6 que se pueden aplicar, mutatis mutandi, a la figura contemplada en el inciso primero del art. 182 OA: a) el mantenimiento de la situación patrimonial contraria a Derecho generada por el hecho delictivo anterior (teoría de la perpetuación o mantenimiento), b) el sacar provecho de la cosa obtenida mediante un delito; c) la ayuda al autor del hecho previo; d) el mantenimiento de la situación patrimonial generada por el delito anterior junto a un peligro abstracto 
de que se cometan en el futuro nuevos delitos; y f) el mantenimiento de la situación generada por el delito y la lesión de los intereses generales en la seguridad, pues el receptador ofrece un motivo para la comisión de delitos patrimoniales en el futuro, al mantener el mercado en que éste se desenvuelve ${ }^{7}$. A ello se agrega la lesión a la Administración de Justicia, en cuanto la receptación también ayuda a frustrar la pretensión de sancionar el delito previo. De este modo, muchos concluyen que constituye un delito pluriofensivo ${ }^{8}$.

En el ámbito aduanero, el delito de receptación reviste características especiales por su particular relación con el comercio ilegal, pues las conductas receptadoras no sólo afectan la Administración de Justicia y perpetúan la situación antijurídica del delito previo, sino que tienen un efecto criminógeno particularmente intenso. Como decíamos, en general, el receptador permite que el autor del delito de referencia siga en la actividad delictiva, lo que implica una lesión más amplia que la mera afectación a la Administración de Justicia, dado que las conductas de receptación "consolidan las condiciones de la actividad criminal y favorecen su continuidad"9. Y esta actividad criminal con la que se vinculan los ilícitos aduaneros se inserta en el amplio contexto del comercio ilegal, con todas las consecuencias perniciosas que éste genera para el desarrollo económico y social: constituye una de las peores formas de competencia desleal, afecta los derechos de los trabajadores que quedan fuera de las garantías que ofrece el empleo formal, propicia la conformación de redes delictivas organizadas - integradas por financistas, transportadores burreros, guardadores, comercializadores, etc.- , se relaciona con

Sistematizadas por Pastor Muñoz, N., Los delitos de posesión y los delitos de estatus: una aproximación político-criminal y dogmática, Atelier, Barcelona, 2005 , p. 98.

Ideas similares se han esgrimido para justificar la sanción de otras conductas post-consumativas, como la posesión de pornografía infantil. Así, Schroeder, F.C., "La posesión como hecho punible", en Revista de Derecho penal y Criminología, 2" época, julio 2004, p. 161, cit. por Pastor Muñoz, Los delitos de posesión y los delitos de estatus, pp. 91-92.

Portados, Robles Planas/Pastor Muñoz, "Tema 12: Delitos contra el patrimonio (III)", en Silva Sanchez (dir.) - Ragúes i Valles (coord.), Lecciones de Derecho penal. Parte especial, Atelier, Barcelona, 2006, p. 247. García Aran, M., "Capítulo XIV: De la receptación y otras conductas afines", en Córdoba Roda/García Aran (dir.), Comentarios al Código penal. Parte especial, Tomo I, Marcial Pons, Madrid, 2004, p. 1135.

52 Revista Ius et Praxis - año $14-\mathrm{n}^{\circ} 1$

El delito de receptación aduanera y la normativización del dolo

delitos tributarios posteriores y, en general, favorece la realización de una serie de conductas ilegales de variada naturaleza. La actitud estatal que se adopte frente a este complejo fenómeno puede afectar, incluso, las relaciones con otros países, en razón de las exigencias y compromisos asumidos al negociar o firmar tratados económicos de libre comercio.

Las peculiaridades enunciadas podrían llevar a caracterizar la receptación aduanera, incluso, como un delito de emprendimiento. Esto, por entender que es parte de un "ciclo global", es decir, de una actividad delictiva más amplia formada por muchas conductas. Con todo, identificarlo como un delito de emprendimiento no resulta conveniente, considerando la poca claridad y gran dispersión que todavía existe al definir esta categoría. Así, los "delitos de emprendimiento" (Unternehmungsdelikte), también conocidos como "delitos de preparación" (Vorbereitungsdelikte), pueden ser definidos - como hace parte de la doctrina alemana y española — como "aquellos tipos que se caracterizan por que, en ellos, la realización de la conducta típica representa el inicio de un iter criminis global cuya fase ejecutiva tendría lugar con la realización de la conducta típica de otro tipo. O dicho de otro modo: la conducta típica de los delitos de preparación constituye materialmente un acto preparatorio de la ejecución del "ciclo total" en que consisten algunos atentados contra ciertos bienes jurídicos"10. Pero otros entienden que el delito de emprendimiento existe cuando el tipo delictivo de que se trate venga a sancionar con la misma pena tanto la consumación como la mera tentativa de dicho delito, o incluso, como delito de emprendimiento impropio, cuando el tipo sanciona con la misma pena a quien efectivamente consuma un delito que a aquel otro que actúa con una tendencia subjetiva dirigida a conseguir dicha consumación delictiva, aunque no la consiga ${ }^{11}$.

En nuestro medio, es calificado como delito de emprendimiento el de tráfico de estupefacientes, configurado por varias conductas alternativas que "aparecen como modalidades independientes de una misma actividad compuesta de una serie indeterminada de acciones, iniciadas o no por el autor, y en las que éste participa una y otra vez"12. Las consecuencias de ello se traducen, fundamentalmente, en el ámbito concursal, pues así caracterizado el delito, las diversas

Gómez Martín, V., "El delito de fabricación, puesta en circulación y tenencia de medios destinados a la neutralización de dispositivos protectores de programas informáticos (art. 270, parr. $3^{\circ} \mathrm{CP}$ ). A la vez, un estudio sobre los delitos de emprendimiento o preparación en ", en RECPC 4-16 (2002), p. 16:8 (disponible enhttp://criminet. ugr.es/RECPC).

Sobre esta clasificación, vid. Roxin, C, Derecho penal. Parte general, I (trad, de la $2^{\mathrm{a}}$ ed. alemana Luzón Peña/ Díaz y García Conlledo/De Vicente Remesal), Civitas, Madrid, 1997, p. 337. 
Politoff, S./Matus, J. P/Ramírez, M. C, Lecciones de Derecho penal chileno, Parte especial, Edit. Jurídica de Chile, Santiago, 2004, p. 593, quienes también califican expresamente el delito de receptación de este modo (p. 368).

Revista Ius et Praxis - año $14-\mathrm{n}^{\circ} 153$

Magdalena Ossandon Widow

conductas eventualmente ejecutadas se deberían reunir en una unidad jurídica de acción, sancionándolas como un único delito. Es decir, se pone el acento en el hecho de que se trata de una participación reiterada en una empresa criminal, en la que cada uno de esos actos son punibles por sí mismos, pero su concurrencia conjunta no implica la configuración de más de un delito. También gozaría de este carácter el delito de almacenamiento de pornografía infantil.

Por último, además del problema conceptual, la categoría de los delitos de emprendimiento no resulta del todo adecuada porque, en el ámbito aduanero, el delito de receptación no podría definirse per se como tal, sino sólo cuando en los hechos se configure de esa manera. Y aunque frecuentemente sea parte de un ciclo de delitos —en su inicio o como su culminación-, lo es tanto como lo son, igualmente, los delitos de hurto o robo, que por lo general se cometen para después "reducir" las especies, como un eslabón más de la cadena delictiva generada. Calificarlos todos como delitos de emprendimiento resultaría excesivo y desnaturalizador.

Aunque estos fenómenos no constituyen el bien jurídico protegido por la figura que comentamos, al menos no su bien jurídico en un sentido técnico o estricto (como pretenden quienes lo consideran un delito contra el orden público económico), de todos modos ellos forman parte de la ratio legis que sostiene y condiciona su tipificación.

Lo anterior justifica la necesidad de instaurar un régimen especial para la receptación aduanera, y puede traducirse también en un trato más severo que el que existe para otros supuestos de encubrimiento. Ambos aspectos —un trato especial y más severo— son contemplados, por lo demás, en la inmensa mayoría de las legislaciones actuales.

\section{Las presunciones a que alude el art. 182 inc. $I^{0}$ y $2^{0}$ de la Ordenanza de Aduana}

De entre las muchas cuestiones que suscita este delito, sólo nos vamos a ocupar de los aspectos subjetivos a los que alude la norma.

Tanto en el primer como en el segundo inciso del art. 182 O A, se contienen referencias a presunciones que merecen una muy diversa valoración.

Comenzaremos con la que contiene el inciso segundo, dirigida al juez, quien al calificar la conducta debería presumir que se configura el conocimiento del origen delictivo de las mercancías, exigido expresamente como elemento del tipo, por el solo hecho de encontrarse en su poder las mercancías objeto del fraude o contrabando.

Esta presunción de conocimiento es abiertamente contraria a la presunción de inocencia que debe regir en materia penal, por imperativo de los artículos 14 párrafo segundo del Pacto

54 Revista Ius et Praxis - año $14-\mathrm{n}^{\circ} 1$

El delito de receptación aduanera y la normativización del dolo

Internacional de Derechos Civiles y Políticos, y $8^{\circ}$ párrafo segundo de la Convención Americana sobre Derechos Humanos, recogida también en nuestro ordenamiento procesal. En efecto, el conocimiento de uno de los elementos del tipo objetivo - el origen de las mercancías - es uno de los componentes necesarios para la imputación de responsabilidad, por lo que presumir su concurrencia es presumir uno de los factores obligados para la declaración de culpabilidad. Esto es exactamente lo contrario a lo que dispone el principio de presunción de inocencia, que impone que se estime inocente a una persona en tanto no fuere condenada por sentencia firme (art. $4^{\circ} \mathrm{CPP}$ ). Dicha sentencia de condena sólo puede ser dictada si el tribunal adquiere, más allá de toda duda razonable, la convicción de que realmente se cometió el hecho punible y que en él le correspondió al acusado una participación culpable y penada por la ley, convicción que debe formarse sobre la base de laprueba producida durante el juicio oral (art. $340 \mathrm{CPP}$ ). En suma, no se puede prescindir de los medios de prueba para tener por concurrente el conocimiento requerido en el tipo.

Ciertamente que — como todo elemento de carácter subjetivo — el conocimiento que tuviere el autor puede ser probado por indicios, es decir, de modo indirecto. El problema es que el inciso segundo del art. $182 \mathrm{O}$ A prescinde de cualquier otro indicio y se conforma con la mera posesión de las mercancías para dar por acreditada su existencia, lo que resulta a todas luces insuficiente. Más aún, una de las circunstancias indiciarías más evidentes que permitiría acreditar el conocimiento del origen ilícito de las mercancías, como es el caso de la posesión de mercancías nuevas destinadas a la venta sin que pueda 
acreditarse su legal internación o su adquisición en el país a una persona determinada, no sirve para castigar por el delito de receptación, sino que es una situación elevada por la propia Ordenanza al carácter de presunción de autoría del delito de contrabando (art. 179 letra e) OA).

Ahora bien, el carácter inconstitucional de esta presunción, que la vuelve inaplicable ${ }^{13}$, ha sido reconocido también por nuestra Corte Suprema ${ }^{14}$, por lo que debe considerarse que sólo es una declaración inútil.

Especialmente en virtud de lo que dispone el artículo $5^{\circ}$ inciso segundo de la Constitución Política de la República, que obliga a las autoridades públicas a respetar las garantías consagradas en instrumentos internacionales sobre derechos humanos, con lo que impide a los órganos jurisdiccionales aplicar una norma de estas características.

Vid. SCS Rol 2.094-00, de 24 de julio de 2001, entiende que el uso de la expresión "se presumen" (en los entonces arts. 187 y 188) no indica necesariamente la existencia de la presunción de dolo que está prohibida constitucionalmente. "... tal presunción no significa una presunción de la existencia del dolo en la actividad de las personas sino que, por el contrario, corresponde al órgano jurisdiccional la obligación de comprobar, por los medios de prueba que determina la ley, tanto la existencia del cuerpo del delito como la participación dolosa o culpable del que realizó la acción".

Revista Ius et Praxis - año $14-n^{\circ} 155$

\title{
Magdalena Ossandon Widow
}

El inciso primero del art. 182, en tanto, se refiere al aspecto subjetivo de este delito, que para su configuración requiere que el sujeto activo sepa que las mercancías que adquiere, recibe o esconde han sido objeto de algún delito aduanero, 0 bien, agrega la norma, que por las circunstancias del caso, deba presumir que tienen ese origen. Al fundamento, admisibilidad, alcance y consecuencias de esta referencia dedicaremos nuestra atención en las páginas siguientes.

\section{El deber de presumir que las mercancías han sido o son objeto de un delito aduanero. Posibles interpretaciones}

Desde el punto de vista terminológico, no cabe duda de que la expresión presumir utilizada al tipificar un ilícito penal adolece de una carga negativa; provoca una reacción emotiva de rechazo, en la medida en que se la vincula, generalmente, con la posibilidad de imputar responsabilidad penal sin contar con prueba suficiente ${ }^{15}$. Sin embargo, es preciso desentrañar su verdadero sentido antes de emitir un juicio sobre su conveniencia o legitimidad.

En Derecho comparado no es extraño que la descripción típica del delito de receptación contenga alusiones similares a la que ahora nos ocupa ${ }^{16}$, entre las cuales es posible encontrar redacciones que permiten delimitar mejor su verdadero alcance y despojarlo de la carga emo-tivo-negativa que trae consigo el empleo del término presumir en la descripción de los tipos

\begin{abstract}
En general, "la presunción jurídica es un medio técnico material que consiste en un juicio general inferido por medio de un razonamiento inductivo a partir de lo que efectúa o la manera cómo se produce comúnmente en determinadas circunstancias el obrar humano. Praesumtio sumitur ex eo quod plerumque fit. Ahora bien, no tratándose, en el obrar humano, que es lo que regula el Derecho, de fenómenos sometidos a los principios de necesidad y constancia de las leyes naturales, es claro que falta el fundamento lógico de la inducción y que, en tales condiciones, la presunción no puede tener un valor apodíctico, sino de mera probabilidad, ni un alcance universal, sino simplemente general. Pero, por lo mismo, en un Derecho eminentemente individualizador, como es el penal, en que no interesa sino lo que y cómo verdaderamente haya acontecido en cada caso singular, no puede, en principio, haber lugar para las presunciones..." Rivacob a y Rivacoba, M., "El principio de culpabilidad en el Código Penal chileno", en Actas de las Jornadas Internacionales de Derecho Penal, en celebración del centenario del Código penal chileno, Edeval, Valparaíso, 1975, p. 86.
\end{abstract}

\begin{abstract}
Nuestros vecinos, Perú y Argentina, contemplan disposiciones con expresiones prácticamente idénticas a la de la OA. Así, en Perú la Ley ${ }^{\circ}$ 28.008 de los delitos aduaneros, tipifica la receptación en su art. 6 en los siguientes términos: "El que adquiere o recibe en donación, en prenda, almacena, oculta, vende o ayuda a comercializar mercancías cuyo valor sea superior a dos Unidades Impositivas Tributarias y que de acuerdo a las circunstancias tenía conocimiento o se comprueba que debía presumir que provenía de los delitos contemplados en esta Ley será reprimido con pena privativa de libertad no menor de tres ni mayor de seis años y con ciento ochenta a trescientos sesenta y cinco días-multa"; el art. 874 del Código Aduanero Argentino, entre las conductas que sanciona como encubrimiento de contrabando incluye la del que (letra d) adquiriere, recibiere o interviniere de algún modo en la adquisición o recepción de cualquier mercadería que de acuerdo a las circunstancias debía presumir proveniente de contrabando.
\end{abstract}

56 Revista Ius et Praxis - año $14-\mathrm{n}^{\circ} 1$

El delito de receptación aduanera y la normativización del dolo

penales. En Gran Bretaña, por ejemplo, la norma de la sección 22 del Theft Act de 1968 permite sancionar a quien recepta bienes robados "sabiendo o creyendo que son cosas robadas"17. En un sentido más objetivo, trasladando este requisito a las características objetivas de la situación o del objeto, el art. $231 \mathrm{~N}^{\circ} 2$ del Código penal portugués sanciona a quien "sin haber previamente asegurado su legítima procedencia, adquiere o recibe, a cualquier título, una cosa que, por sus cualidades o condiciones, o por el precio en que es ofrecida, es razonable sospechar que proviene de un hecho ilícito 
contra el patrimonio"; como en Cuba, en que la referencia es a "bienes que la persona que los presente, o la ocasión o circunstancias de la enajenación, evidencien o hagan suponer racionalmente que proceden de un delito". De este modo, lo que se debe acreditar es el conocimiento de dichas circunstancias, en tanto que lo penalmente prohibido es realizar ciertas conductas respecto de bienes que tengan la apariencia de ser la consecuencia de un delito, sin perjuicio que desde el punto de vista objetivo también se exija que efectivamente tengan ese carácter ${ }^{18}$.

Ahora bien, como en Chile las opiniones doctrinales son casi inexistentes en relación con este deber de presumir a que se refiere la figura específica de receptación aduanera, podemos aproximarnos a las posibilidades interpretativas de dicha expresión haciendo un paralelo con las que se han desarrollado a propósito del delito de receptación consagrado en el art. 456 bis A del Código penal. El elemento subjetivo en ese delito se describe como el conocimiento del origen de las especies o, agrega la norma, "no pudiendo menos que conocerlo". Aunque aquí no se habla de un deber de presumir dicho origen, no cabe duda de que a ambas expresiones se les puede asignar un sentido similar.

Es posible distinguir en nuestra doctrina diversas formas de interpretar estas referencias.

a) En primer lugar, se las ha considerado como consagración de una hipótesis de responsabilidad objetiva. Es el alcance que Guzmán Dálbora le asigna tanto a la norma aduanera ${ }^{19}$ como a la que contiene el Código penal. En general, este autor entiende que "el conoci-

\begin{abstract}
Expresión que permitiría incluir los casos de ceguera jurídica, pero que excluye la mera sospecha, según As-hworth, Principles of Criminal Law, Clarendon Press, Oxford, 1991, reimpresión 1995, p. 347, cit. por MacKinnon Roehrs, J., Autoría y participación y el delito de receptación, Lexis Nexis, Santiago, 2004, p. 172. Existe un proyecto en tramitación -Boletín $\mathrm{N}^{\circ}$ 4244-07- para modificar el delito de receptación e incorporar una falta similar, que asume en parte este modo de legislar. La falta propuesta sería del siguiente tenor: Artículo 496 N $39 \mathrm{CP}$ : "El que reciba o adquiera una cosa sin haberse cerciorado previamente de su legítima procedencia sufrirá la pena de multa de 1 a 5 UTM, cuando las condiciones en que se ofrece la cosa, sea por su calidad, las características del oferente o el precio propuesto, hagan sospechar razonablemente un origen ilícito". Guzmán Dálbora, Contrabando y fraude aduanero, p. 55.
\end{abstract}

Revista Ius et Praxis - año $14-n^{\circ} 157$

Magdalena Ossandon Widow

miento efectivo y actual del delito del que proceden las especies, es exigencia ineludible en un pensamiento culpabilista y liberal, y no puede reemplazarse por un simplificador debía conocer — que haría penetrar la ejecución culposa— ni, menos, por un sistema de presunciones construidas sobre la mera tenencia o posesión de aquéllas"20. Al intentar otras opciones interpretativas, Guzmán Dálbora se manifiesta contrario a la opinión que ve en las palabras no pudiendo menos que conocerlo una alusión a la prueba por presunciones, porque entonces se estaría pasando por alto que la prueba del dolo es siempre indirecta. Tampoco comparte que este problemático giro gramatical pueda significar la admisión de una forma culposa de receptación, la que debería ser explícita según lo exige el artículo $10 \mathrm{~N}^{\circ} 13 \mathrm{CP}^{21}$. Por todo lo anterior, concluye que estamos ante un delito de sospecha, más aún, que aquí "la ley ha remachado una responsabilidad objetiva que, según mí modesto entender, resiste a pie firme cualquier interpretación culpabilista y constituye una ominosa supervivencia penal en el Código"22. En el mismo sentido se ha pronunciado el prof Kün-semüller, quien también lo califica como delito de sospecha ${ }^{23}$.

Frente a esta opción radical, otras explicaciones pretenden asignar a las expresiones que nos ocupan un sentido respetuoso del principio de culpabilidad propio de un Derecho penal liberal.

b) Así, en segundo lugar, se ha planteado una tesis totalmente opuesta a la anterior, en cuanto asigna una función garantista a estas menciones. Partiendo de la idea de que nuestro Código penal consagra una presunción general de dolo en su art. $\mathrm{I}^{\mathrm{o}}$, se entiende que a través de la frase "el que conociendo su origen o no pudiendo menos que conocerlo", la ley no establece un elemento subjetivo del tipo, sino que exige la prueba expresa del dolo, directo o eventual, haciendo inaplicable a esta figura la presunción antedicha ${ }^{24}$.

La corrección de esta tesis requiere, obviamente, que se acepte su premisa. Y ya en este punto puede ser descartada, porque esa supuesta presunción de dolo - aunque puede conside-

Guzmán Dálbora, J.L., "Luz y sombras en la "nueva" disciplina de la receptación en el Código penal chileno", en Gaceta Jurídica N 188, 1996 , p. 83.

Guzmán Dálbora, "Luz y sombras en la "nueva" disciplina de la receptación...", n. 45 y n. 46. Guzmán Dálbora, "Luz y sombras en la "nueva" disciplina de la receptación...", p. 84.

Künsemüller Loebenfelder, C, "Importancia dogmática y político-criminal de los principios limitadores del ius puniendi", en Gaceta Jurídica № 264 , 2002 , p. 10.

Es la posición más tradicional de autores como Amunátegui, F., "Maliciosamente " y "A sabiendas " en el Código Penal chileno, Edit. Jurídica de Chile, Santiago 1961, p. 61 y ss., al menos respecto de la expresión "a sabiendas"; y Novoa, E., Curso de Derecho Penal chileno, I, Edit. Jurídica de Chile, Santiago, 1960, p. 502. Recogida

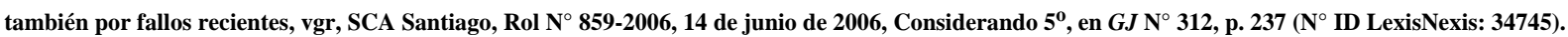


58 Revista Ius et Praxis - año $14-\mathrm{n}^{\circ} 1$

El delito de receptación aduanera y la normativización del dolo

rarse la posición tradicionalmente mayoritaria en nuestro medio, en especial en la jurisprudencia—, está siendo progresivamente rechazada, dado que contradice principios limitadores del Derecho penal que en la actualidad gozan de reconocimiento constitucional y legal ${ }^{25}$.

Por lo demás, tampoco resulta de recibo atribuir el sentido expuesto a la expresión legal sin forzar sus términos. Tanto el "no pudiendo menos que conocer" del art. 456 bis A CP, como el "debiendo presumir" del art. 182 OA, se refieren al imputado y sus deberes de conocimiento, y no al juez para recargar su labor con mayores exigencias probatorias.

c) Una tercera posibilidad interpretativa es la que plantea Etcheberry, quien entiende que la expresión legal no es sino una forma poco feliz de expresar que el conocimiento del origen de las cosas puede constar directamente, es decir, por testigos, documentos, confesión; o bien indirectamente, por medio de presunciones ${ }^{26}$.

Sin embargo, a esta opción se le puede objetar que transforma la mención legal en una referencia inútil, porque el dolo, como todo hecho psicológico, se prueba precisamente de esta forma, es decir, por indicios ${ }^{27}$.

d) Por último, parece imponerse paulatinamente la idea de que estas referencias legales permitirían sancionar las conductas típicas también en los supuestos en que concurra dolo eventual ${ }^{28}$. Ello se debe a que, según una interpretación bastante generalizada, cuando la

Vid. sobre las distintas posiciones doctrinales, Künsemüller Loebenfelder, C, Culpabilidad y pena, Edit. Jurídica de Chile, Santiago, 2001, pp. 250 ss., y Gallaher Hucke, A., La presunción de inocencia y la presunción de voluntariedad, Fundación Fernando Fueyo L., Santiago, 1996, passim. Etcheberry, Derecho Penal, III, p. 361.

Es la forma de argumentar de los fallos, que se tienen que basar en indicios para tener por acreditado el conocimiento necesario. Así, por ejemplo, en "las circunstancias reconocidas de haberlas adquirido de desconocidos, en un bajo precio y de que se trata de una persona que comercia habitualmente con especies usadas, sin que lleve un debido control de origen de lo que compra" (SCA San Miguel, Rol 1774-1997, de 3 de abril de 1998), que el sujeto "conoció a la persona que le vendió el televisor en la cárcel, y el precio bajísimo que le pagó" (SCS, Rol 4112-2003, de 20 de octubre de 2003), que "recibió y adquirió de otro tercero, sin pedir ni solicitar la documentación respectiva, ni guía de Libre Tránsito, doce vacas y una vaquilla de raza lechera" (Autos CS, Rol 4172-2000, de 17 de julio de 2001); "que portaba las especies antes sustraídas, sin poder precisar si fueron hurtadas o robadas, botándolas al ser sorprendido, demostrando con ello, según la Corte, que conocía su procedencia ilícita" (SCA Valparaíso Rol 3-2007, de 28 de febrero de 2007). Volveremos sobre la prueba del dolo infra V. En este sentido, Aguilar Aráñela, C, Delito de receptación: doctrina y jurisprudencia, Edit. Metropolitana, Santiago, 2002, p. 22, Mackinnon Roehrs, Autoría y participación y el delito de receptación, p. 202, Polito-ff/Matus/Ramírez, Lecciones de Derecho penal chileno, PE, p. 368 (quienes incluso parecen interpretar el dolo eventual de modo diferente al tradicional, pues ni siquiera sería necesario que el agente se hubiere representado

Revista Ius et Praxis - año $14-\mathrm{n}^{\circ} 159$

Magdalena Ossandon Widow

ley contiene alguna exigencia subjetiva especial, sea de conocimiento —-"conociendo", "con conocimiento de causa", "a sabiendas", "constándole", etc.—, o de voluntad —-maliciosamente", "de propósito", etc.— el ámbito penalmente relevante resulta configurado sólo por las conductas cometidas con dolo directo ${ }^{29}$. Entonces, para evitar esta limitación sin dejar de poner el acento en el necesario conocimiento sobre el origen de las especies, la propia descripción típica se encarga de abrir de nuevo la posibilidad de imputación a los supuestos de dolo eventual. Quienes sustentan esta posición, en todo caso, concuerdan en que en ningún caso ella implica la posibilidad de sancionar la conducta meramente culposa.

Aeste respecto, resulta interesante repasar la discusión parlamentaria provocada al tramitarse el proyecto de ley para crear la Unidad de Análisis e Inteligencia Financiera y regular el lavado o blanqueo de activos, Boletín N²2975-07, que culminó con la dictación de la Ley $\mathrm{N}^{\circ}$ 19.913. La opción que ahora analizamos fue la forma de interpretar la referencia al necesario conocimiento del origen de los bienes que contenía el proyecto original en el delito de lavado de activos ${ }^{30}$. El Ejecutivo quiso agregar, entonces, una alusión a lo que el autor "debía saber", a fin de que no hubiera dudas acerca de la sanción del dolo eventual, pero esa expresión volvió a ser controvertida porque parecía implicar una presunción de dolo, según Bustos Ramírez. La solución inicial fue eliminar cualquier referencia de orden subjetivo. Con posterioridad, en el Senado fue rees-

y aceptado la posibilidad de que las especies fueren objeto de un delito, sino que bastaría con un conocimiento potencial del origen de las especies receptadas); Valdivia Rivas, C./Vargas Otte, G., "Estrategias de intervención en el mercado de bienes robados", Fundación Paz Ciudadana, Julio 2006 (disponible en http://www. pazciudadana.cl/publicaciones-informacion-estudios.php).

En este sentido, aunque lo admite sólo como una posibilidad, sin pretender asignarle validez general, Cousiño, L., Derecho Penal chileno, I, Edit. Jurídica de Chile, Santiago, 1975, p. 769 y ss.; Politoff, S./Matus, J. P./Ramírez, M. C, Lecciones de Derecho penal chileno, Parte general, Edit. Jurídica de Chile, Santiago, 2004, p. 280. En particular, para el tipo de parricidio, Bustos, J./Politoff, S./Grisolía, F., Derecho penal chileno. Parte Especial, T. I, Edit. Jurídica de Chile, Santiago, 1971, p. 119; aunque en este caso su postura se sustenta exclusivamente en razones de política-criminal; mientras que en relación con el uso de la expresión "a sabiendas" en las lesiones graves tipificadas en el art. 398 CP, admiten la suficiencia del dolo eventual (p. 308). Respecto del delito de lavado de activos, también asumen esta posición Politoff, S., "El lavado de dinero", en Politoff/Matus (eds.), Lavado de dinero y tráfico ilícito de estupefacientes, Lexis Nexis, Santiago, 1999, p. 74 ss. y Silva Silva, H. "El delito de lavado de dinero proveniente del tráfico ilegal de drogas como un delito internacional", en Revista de Derecho, Universidad de Concepción, enero -junio 1996, p. 147; en contra, 


\begin{abstract}
Hernández Basualto, H., "El delito de lavado de dinero ", Informe en Derecho para la Unidad Especializada de Lavado de Dinero y Delitos Económicos de la Fiscalía Nacional del Ministerio Público, 2004, p. 19 (disponible en http://www.ministeriopublico. cl/RepositorioMinpu/Archivos /minpu/Informes\%20en\%20derecho/HECTOR\%
\end{abstract} 20HERNÁNDEZ\%201avado. doc).

Vid. las opiniones del Consejo de Defensa del Estado y del prof Bustos Ramírez en el Informe de la Comisión de Constitución, Legislación y Justicia, de 4 de septiembre de 2002.

60 Revista Ius et Praxis - año $14-n^{\circ} 1$

El delito de receptación aduanera y la normativización del dolo

tablecida la expresión original —sabiendo, que luego se modificó por a sabiendas para emplear la terminología más habitual - porque se entendió que debía restringirse el tipo a la conducta cometida con dolo directo, de conformidad con los requisitos impuestos por la Convención de las Naciones Unidas contra el tráfico ilícito de estupefacientes y sustancias sicotrópicas, de 1988 (art. $3^{\circ} \mathrm{N}^{\circ} 1$ ), y por las características intrínsecas de esa figura así como de su elevada penalidad ${ }^{3}$.

Ahora bien, la norma sobre lavado de activos incluye también, en el inciso $4^{0}$ del art. 27, una modalidad culposa con pena rebajada en dos grados. Aunque algunos la estiman una figura criticable, su inclusión se justificó como parte de una tendencia internacional —está en el reglamento modelo de la Comisión Interamericana contra el Abuso de la Droga, CICAD, y en otras legislaciones - y se entiende dirigida a personas que por la función que desempeñan tienen un deber de cuidado específico, mayor que el resto (abogados, bancos y entidades financieras), pues entonces el desconocimiento del origen ilícito de los bienes podría calificarse como negligencia inexcusable. Quienes restringen la figura principal a la comisión con dolo directo, han de incluir los supuestos de dolo eventual en este inciso cuarto, para evitar una laguna de punibi-lidad entre el dolo directo y la culpa, con la consiguiente rebaja de dos grados de la pena.

Con todo, tal como en los casos anteriores, si no se comparte la premisa inicial, la expresión legal pasa a ser superflua. Es decir, si la referencia al necesario conocimiento respecto del origen de las especies o mercancías no implica una restricción al dolo directo, entonces no tiene sentido incluir una expresión que permita sancionar el dolo eventual, porque la regla general es que éste resulta naturalmente comprendido en toda descripción típica.

Y, ciertamente, existen argumentos para controvertir esa tesis inicial ${ }^{32}$. En primer lugar, desde una perspectiva histórica, pues al incorporarse muchas de esas expresiones en el Código penal el dolo eventual era desconocido para nuestro legislador. Desde este punto de vista, entonces, resulta más lógico atribuirles el significado de dejar sin efecto la presunción de voluntariedad del art. $\mathrm{I}^{\mathrm{O}} \mathrm{CP}$, como sucedía en el derecho español, o para insistir en el carácter doloso de la conducta,

Vid. el Informe de la Comisión de Constitución, Legislación, Justicia y Reglamento, de 28 de abril de 2003. Expuestos detalladamente por Hernández Basualto, "El delito de lavado de dinero", pp. 10-19, para descartar que la exigencia de conocimiento que contiene dicha figura permita excluir del ámbito de la tipicidad aquellas conductas de lavado de dinero realizadas con dolo eventual, un razonamiento que atribuye a "una cierta inercia frente a conclusiones extraídas de giros azarosos del texto legal, postuladas pero nunca debidamente fundadas". Incluso, uno de los autores más críticos frente a la redacción del delito de receptación, admite que "dicho conocimiento, en la misma medida en que la ley no reclame el ánimo de lucro, es perfectamente compatible con el dolo eventual", Guzmán Dálbora, "Luz y sombras en la "nueva" disciplina de la receptación...", p. 84

Revista Ius et Praxis - año 14 - n 161

Magdalena Ossandon Widow

como solía hacer el Código belga ${ }^{33}$. En segundo lugar, el criterio sistemático impide conferirles de un modo general el sentido de restringir las conductas típicas a aquellas realizadas con dolo directo, porque es fácil advertir que estas expresiones han sido empleadas de modo asistemático, sin un objetivo bien delimitado y, en no pocas ocasiones, sin reparar en su significado y alcance ${ }^{34}$. En tercer término, el derecho comparado también ofrece la posibilidad de atribuirles un significado diverso. Sin ir más lejos, en España, el conocimiento de la comisión de delito previo en la figura de receptación, exigido sin mitigaciones en el tipo, es considerado el elemento nuclear y el más controvertido ${ }^{35}$; pero una expresión del todo equivalente en el delito de lavado de dinero (art. $301 \mathrm{CP}$ ), según el parecer mayoritario, no configura un obstáculo para admitir la comisión con dolo eventual ${ }^{36}$; y lo mismo ocurre en muchas otras figuras. En general, la cuestión de si una referencia subjetiva excluye o no el dolo eventual de un tipo se hace depender tanto de la clase de expresión de que se trate como, especialmente, de un análisis del sentido de la norma ${ }^{37}$.

Cabe advertir, por último, que en el caso específico del delito de receptación del art. 456 bis A, durante la discusión parlamentaria se dejó constancia de que la expresión "no pudiendo menos que conocer su origen" fue incorporada, a pesar de los reparos doctrinales, en vista de la dificultad de probar que la persona que recepta ha conocido efectivamente el delito de robo o 


\begin{abstract}
En este sentido, Novoa, Curso de Derecho Penal chileno, I, p. 502, destaca la imprecisión del lenguaje usado en el Código penal y, más aún, en leyes especiales posteriores, lo que obliga a buscar el significado de las referencias subjetivas que eventualmente contengan las descripciones típicas en las ideas directrices que han inspirado al legislador y no en las palabras de que se valió.

El art. 298 del CP Español de 1995 exige "conocimiento de la comisión de un delito contra el patrimonio o el orden socioeconómico". Existe consenso para entender que no se requiere conocimiento preciso de la concreta figura delictiva previamente ejecutada ni basta con la simple sospecha, pero respecto de esto último sólo algunos llegan a afirmar que no sería suficiente el dolo eventual, vgr. García Aran, "Capítulo XIV: De la receptación y otras conductas afines", p. 1137. El Tribunal Suprema ha dicho que "la Jurisprudencia no exige un conocimiento pormenorizado del hecho punible del que provienen los hechos receptados, sino simplemente el conocimiento del origen delictivo de los mismos y que, al efecto, no excluye el dolo eventual, razón por la cual es suficiente con que el autor haya tenido que representarse ese peligro de la realización del tipo con su acción" (el destacado es nuestro), STS de 31 de enero de 1997, pon. Bacigalupo Zapater.
\end{abstract}

\begin{abstract}
Quienes niegan esa posibilidad en algunos casos — especialmente respecto del art. $301.1 \mathrm{CP}$ — lo hacen exclusivamente por la exigencia adicional de un elemento subjetivo del tipo, en la medida en que la conducta se debe desplegar "para ocultar o encubrir su origen ilícito, o para ayudar a la persona que haya participado...". Lo destaca Hernández Basualto, "El delito de lavado de dinero", pp. 18-19, con abundantes referencias bibliográficas. Por todos, Martínez-Buján Pérez, C, Derecho penal económico y de la empresa. Parte general, 2" edición, Tirant lo Blanch, Valencia, 2007, pp. 376-377, analiza varios ejemplos con locuciones como "a sabiendas", "dolosamente" e "intencionalmente". También Ragúes i Valles, R., La ignorancia deliberada en Derecho penal, Atelier, Barcelona, 2007, p. 105, considera que las notables discrepancias acerca de si estas previsiones legales excluyen o no la posibilidad de aplicar el dolo eventual se debe a que su presencia no se explica por una decisión político-criminal consciente, sino por una serie de casualidades históricas o legislativas, y porque según como se interpreten podrían provocar lagunas de punibilidad no justificadas.
\end{abstract}

62 Revista Ius et Praxis - año $14-n^{\circ} 1$

El delito de receptación aduanera y la normativización del dolo

hurto del cual provienen las especies que posee o comercializa ${ }^{38}$. Sin embargo, este es un dato poco determinante, que bien puede usarse como argumento en favor o en contra de varias de las posiciones expuestas.

Además de estas cuatro opciones interpretativas, podemos encontrar todavía una quinta, que responde a una forma parcialmente diversa de entender el sistema del Derecho penal y, en su interior, el dolo como categoría de imputación. Ésta se corresponde con una visión funcio-nalista y permite sostener que las menciones que ahora analizamos sirven para dar cabida a un concepto normativo de dolo. Pero antes de revisar esta alternativa conviene hacer algunas aclaraciones previas sobre la normativización de los conceptos penales y su utilidad respecto de la imputación subjetiva del delito.

\title{
IV. El proceso de normativización
}

En los últimos decenios la dogmática penal se ha desarrollado hacia una progresiva normativización de su objeto de estudio, al considerar que la teoría del delito debe estructurarse a partir de sus propias normas y según su finalidad específica, con independencia — mayor o menor, según los autores — de categorías ontológicas y prejurídicas. Normativización que es reconocida y asumida incluso por quienes manifiestan sus reservas o críticas frente a los intentos más extremos ${ }^{39}$.

$\mathrm{Al}$ asumir este punto de vista, resulta necesario también reconocer que cuando se condena a una persona por haber cometido un delito, el sistema no se limita a declarar una culpabilidad preexistente, sino que lo que hace es imputar responsabilidad, de conformidad con la misión que se asigne al Derecho penal en la sociedad moderna $^{40}$. La asignación de responsabilidad penal, en consecuencia, "es un acto de atribución de significado social y no una constatación de hecho del mundo de la naturaleza, esto es, un saber práctico y no teórico"41.

Informe de la Comisión de Constitución, Legislación, Justicia y Reglamento, en segundo trámite constitucional,

$1^{\circ}$ de agosto de 1995, Boletín $N^{\circ} 1.363-07$.

Vgr., Mir Puig, S., "Límites al normativismo en Derecho penal", en obra colectiva Homenaje al profesor Dr.

Gonzalo Rodríguez Mourullo, Thomson-Civitas, 2005, passim (también disponible enRECPC 07-18 (2005), p.

18:1-24, http://criminet.ugr.es/recpc/07/recpc07-18.pdf)

Este reconocimiento no puede conducir a utilizar el sistema de modo autoritario sino que, al contrario, obliga a

retraer la imputación jurídico-penal tanto como sea posible. Cfr., con referencias a Neumann, Silva Sánchez, J.

M., "Evolución de la dogmática del Derecho penal en Alemania", en Estudios de Derecho penal, Grijley, Lima,

2000, p. 272.

file://C:\Documents and Settings\Prestamo\Configuración local\Temp\Rar\$EX07.500\... 29/08/2008 
Martínez-Buján Pérez, Derecho penal económico y de la empresa, p. 367.

Revista Ius et Praxis - año 14 - n 163

Magdalena Ossandon Widow

Ahora bien, esta forma de concebir los diversos conceptos y categorías penales ha tenido un desarrollo heterogéneo al interior del sistema. Así, por ejemplo, mientras en el marco de la tipicidad las tesis sobre la imputación objetiva han sido objeto de un amplio debate y han tenido una rápida acogida, en relación con el aspecto subjetivo del tipo el proceso ha sido menos fecundo. Esto puede deberse, en parte, a que en esta materia se ha puesto en duda que se pueda objetivar y normativizar el elemento subjetivo del delito, como se ha hecho con el objetivo, prescindiendo de toda consideración psicológica, o bien, porque se estima que el acto psicológico de conocer y querer algo cuando se actúa es de capital ayuda para concretar la imputación ${ }^{42}$.

Para asumir una posición en este debate, es necesario revisar brevemente el concepto psicológico de dolo y los problemas que genera, para entonces aludir a la visión normativa.

\section{Concepción psicológica de dolo}

Todas las opciones analizadas sobre el significado de las expresiones "debiendo presumir" o "no pudiendo menos que conocer" en los delitos de receptación, se vinculan con un concepto psicológico de dolo. Concepto que, sobre una base en común, puede presentar algunas divergencias en cuanto a sus elementos y su ubicación sistemática. La posición más clásica es la que concibe el dolo como conocer y querer la realización del tipo, a lo que se añade el conocimiento sobre la antijuridicidad de la conducta, que incorpora un componente de malicia que permite vincularlo con el juicio de reproche propio de la culpabilidad. Más modernamente, por diversas razones que parten con la influencia del esquema propuesto a partir de finalismo, se ha despojado el concepto de ese conocimiento de la antijuridicidad. Como un concepto neutro - conocer y querer la realización del tipo— - se le ubica dentro de la tipicidad.

En la dogmática comparada existe una gran discusión en orden a si realmente es necesario exigir un elemento volitivo en el dolo, o, al menos, si éste queda en igualdad de rango con el cognitive Si desde una perspectiva lógica puede afirmarse que entre ambos elementos existe una relación de dependencia o implicancia, según la cual "siempre que alguien lleva a cabo una conducta determinada bajo determinadas circunstancias conociendo las características tanto de la conducta como de las circunstancias, quiere a la vez realizar la conducta con dichas circuns-

\footnotetext{
Cfr. Cuello Contreras, J., "Fundamentos para un sistema lógico-funcional de Derecho penal. Más allá del ontologismo y el normativismo", en RECPC 08-01 (2006), p. 01:1-18; http://criminet.ugr.es/recpc/08/recpc08-01.pdf, quien descarta lo primero al analizar los sistemas de Jakobs y Frisch, pero propone un sistema onto-teleológico, en el que se complementen las perspectivas ontológicas y normativas, de tal modo que el sistema considere las limitaciones del comportamiento humano al que se dirigen las normas, para no forzar la realidad sobre la que se pretende influir con ellas.
}

64 Revista Ius et Praxis - año $14-n^{\circ} 1$

El delito de receptación aduanera y la normativización del dolo

tandas"43, entonces el dolo puede considerarse acreditado cuando se ha demostrado el actuar consciente del sujeto, prescindiendo de la prueba del elemento volitivo, que quedaría relegado a un segundo plano.

En principio esta posición fue criticada, especialmente, porque parecía significar que la culpa consciente quedaría integrada dentro del contenido del dolo eventual, con todas las consecuencias político-criminales que ello envuelve. Sin embargo, la idea de prescindir del elemento volitivo se ha impuesto, precisamente, a la hora de establecer criterios para diferenciar entre dolo eventual y culpa consciente ${ }^{44}$.

Con todo, no nos ocuparemos especialmente de la conveniencia o no de asumir un enfoque cognitivo del dolo, fundamentalmente por dos razones. Primero, porque las concepciones que reducen el dolo al elemento cognitivo no difieren esencialmente de las tesis tradicionales, en la medida en que muchas de ellas exigen un conocimiento no sólo de los datos fácticos, sino también del resultado típico o, al menos, del riesgo para la producción de dicho resultado. Entonces, no tiene mucho sentido exigir además un elemento volitivo específico, pues en el fondo lo que se ha hecho es trasladar la característica volitiva de la decisión en contra del bien jurídico al contenido del conocimiento ${ }^{45}$. Y, segundo, porque entre las tesis cognitivas algunas siguen concibiendo el elemento intelectual del dolo como una realidad psicológica, al modo tradicional, mientras que otras asumen un criterio normativo. No suponen, por lo tanto, ninguna 
decisión en lo que se refiere a este aspecto que es el que ahora nos interesa.

Sin embargo, este concepto ha sido objeto de varias objeciones, entre las que destaca el hecho de que si se considera el dolo como proceso psicológico resulta imposible reconducir a un género común las diversas actitudes psicológicas que normalmente se incluyen bajo esta noción ${ }^{46}$.

Hruschka, J., "Sobre la difícil prueba del dolo" (trad. Ragúes i Valles), en Hruschka, Imputación y Derecho penal. Estudios sobre la teoría de la imputación, Aranzadi, Navarra, 2005, p. 146.

Vid., por todos, Hava García, E., "Dolo eventual y culpa consciente: criterios diferenciadores", en Anuario de Derecho penal, Asociación Peruana de Derecho penal, 2003, p. 114, que alude a las monografías de Feijoo Sánchez, B., "La distinción entre dolo e imprudencia en los delitos de resultado lesivo: Sobre la normativización del dolo", en Cuadernos de política criminal, N 65, 1998, p. 279 ss.; Laurenzo Copello, R, Dolo y conocimiento, Tirant lo Blanch, Valencia, 1999 , p. 245 y ss. y Ragúes i Valles, R., El dolo y su prueba en el proceso penal, J. M. Bosch Editor, Barcelona, 1999, passim.

Lo destaca, Martínez-Buján Pérez, Derecho penal económico y de la empresa, pp. 359-361. Por todos, Laurenzo Copello, Dolo y conocimiento, p. 186 y ss. y MartínezBuján Pérez, Derecho penal económico y de la empresa, p. 347.

Revista Ius et Praxis - año $14-n^{\circ} 165$

Magdalena Ossandon Widow

Mayor relevancia tiene la crítica que se refiere al dilema probatorio a que conduce. Porque según la concepción psicológica, el dolo resulta entendido, en la práctica, como un hecho más que hay que probar dentro del proceso penal. Un hecho "interno", pero que se sitúa en el mismo nivel que los demás hechos relevantes para la decisión condenatoria. Sin embargo, concebido como fenómeno psicológico, en estricto rigor y como se afirmaba ya en el siglo XVI, "dolus veré probari nonpotest, cum in animo consistaf, es decir, "el dolo no puede probarse realmente porque se trata de un fenómeno espiritual"47. Podría pensarse que existe plena prueba del dolo cuando ella se construye a partir del sujeto que confiesa, pues entonces se revela lo que sucedió en su interioridad. Pero la confesión por sí sola tampoco es, ni puede ser, plena prueba —no se podrá condenar a una persona con el solo mérito de su propia declaración, dispone el inc. $3^{\circ}$ del art. $340 \mathrm{CPP}$ - por lo que no constituye más que un indicio de la existencia del dolo. Por eso es discutible que el dolo sea accesible a la prueba, porque "si partimos de que las confesiones son sólo indicios — simples indicios- de la existencia de dolo, las circunstancias externas del hecho podrán ser también tales indicios, pero ninguno de ellos será suficiente para el dolo, planteándose entonces la pregunta de cómo una acumulación de indicios insuficientes puede aportar la prueba del dolo"48. En definitiva, como concluye Ragúes i Valles ${ }^{49}$, si se concibe el dolo en sentido tradicional, como un fenómeno psicológico, ajeno y pretérito, no hay forma de probar de modo fehaciente su existencia, porque prácticamente todos los medios probatorios con los que puede contar el juez para hacerlo incorporan un cierto grado de riesgo de que los hechos que se den por probados no coincidan con los fenómenos psicológicos realmente acaecidos en el fuero interno del sujeto. En consecuencia, nunca sería posible condenar por un delito doloso sin asumir el riesgo de estar instrumentalizando al sujeto condenado.

La dificultad en la prueba del dolo, en el contexto que ahora nos interesa, se trasluce tras el debate interpretativo sobre las expresiones "no pudiendo menos que conocerlo" y "debiendo presumir" contenidas en los tipos de receptación. En efecto, las tres primeras formas de interpretarlas se refieren directamente a cuestiones probatorias. La primera, al estimar que dichas locuciones configuran hipótesis de responsabilidad objetiva o de sospecha, fundamentalmente, porque implicarían una presunción de que el sujeto ha actuado concurriendo el conocimiento efectivo y actual del delito del que proceden las especies, presunción que resulta contraria a las exigencias del principio de culpabilidad ${ }^{50}$. La segunda, a la inversa, porque las entiende como

MKSCARDi,Conclusionesprobationum, vol. 2,1661,p. 69, cit. por Hruschka, "Sobre ladifícilpruebadeldolo",p. 154.

Hruschka, "Sobre la difícil prueba del dolo", p. 153 (destacado en el original).

Ragúes i Valles, El dolo y su prueba en el proceso penal, p. 259 ss.

Künsemüller Loebenfelder, al fundamentar su voto disidente en la SCA San Miguel, de 3 de abril de 1998, Rol

N 1.774-97, advierte que "la presunción de conocimiento -esto es, de dolo- que, derivada del comercio habitual

de especies usadas, establecía el artículo 454, inciso final, fue eliminada en la nueva normativa introducida por

66 Revista Ius et Praxis - año $14-n^{\circ} 1$

El delito de receptación aduanera y la normativización del dolo

una excepción a la presunción general de dolo, que obliga al tribunal a probar expresamente este elemento. Y la tercera, 
porque les asigna el significado de hacer posible el empleo de presunciones como medio probatorio respecto del conocimiento exigido por el tipo. Incluso la cuarta opción interpretativa, que concibe las expresiones legales como una ampliación del tipo a los supuestos de dolo eventual, indirectamente también dice relación con la prueba de este elemento, pues en la práctica implica afirmar que no resulta indispensable probar que existía el propósito o intención específico de cometer la conducta típica (dolo directo), sino que bastaría con demostrar que el sujeto se representó esa posibilidad sin rechazarla — sin que existan antecedentes que permitan afirmar que la rechazaba — para imputarle subjetivamente la conducta.

Pero, si aceptamos que el dolo, como fenómeno psicológico, no puede probarse fehacientemente, entonces todas esas posibilidades de interpretación pierden sentido, aparecen como "una turbina que gira en el aire fuera de sus engranajes"51. En efecto, porque a partir de esa premisa la infracción del principio de culpabilidad denunciada desde la primera postura se haría extensible a todo el Derecho penal, el que pasaría a ser prácticamente inaplicable. Por su parte, la obligación de probar el dolo y la posibilidad de hacerlo por medio de indicios se manifiestan desde esta perspectiva como mera retórica, desprovista de contenido, precisamente porque estamos afirmando que nunca es posible probar fehacientemente el dolo. Lo propio ocurre cuando se alude a una ampliación del tipo al dolo eventual, pues éste último se encuentra en el mismo atolladero probatorio en que estaría el dolo directo.

La única forma de superar esta encrucijada es reformulando el concepto de dolo, para dejar de entenderlo como un hecho que existe y debe ser probado; es decir, como un hecho interno cuya existencia podría comprobarse por métodos científicos, al igual que los hechos externos.

Desde la óptica de la filosofía del lenguaje y, en particular, las teorías del Wittgenstein tardío, puede afirmarse que "la libertad, las acciones, la responsabilidad, la culpabilidad e incluso el dolo no aparecen en el juego del lenguaje de los científicos de la naturaleza. Por tanto, no podemos tratarlos como hechos y tranquilizarnos pensando en que se trata simplemente de hechos especiales, es decir, de hechos internos" ${ }^{\prime 52}$, porque no gozan de ese carácter fáctico.

la ley $\mathrm{N}^{\circ}$ 19.413, de manera que ella no puede ser actualmente empleada para construir una suerte de responsabilidad penal objetiva, que contradice violentamente
las garantías del principio de culpabilidad (Cfr. José Luis Guzmán Dálbora, "Política Criminal y Reforma Penal en Chile (1991-1995)", en obra colectiva Política Criminal y Reforma Penal, Edit. Jurídica ConoSur Ltda., p. 43 y ss.)".

Parafraseando a Wittgenstein, L., Investigaciones filosóficas (trad. García Suárez/Moulines), Barcelona, 1988, § 38, 88, 132, etc. Hruschka, "Sobre la difícil prueba del dolo", p. 153 (destacado en el original).

Revista Ius et Praxis - año 14 - n 167

Magdalena Ossandon Widow

En definitiva, no es plausible una concepción psicológica del dolo dentro del sistema de imputación jurídico-penal. Pero no sólo por eso debe ser descartada, sino también porque, por principio, al Derecho penal no le sirve una realidad puramente psicológica, sino que requiere otros referentes que le permitan cumplir de un modo más efectivo su función en la sociedad ${ }^{53}$. El tema, entonces, debe dejar de plantearse desde una perspectiva puramente ontológica para asumir un carácter fundamentalmente normativo.

\section{Concepción normativa de dolo}

Antes de revisar la posibilidad de asignar un contenido normativo al dolo, siguiendo la advertencia de Martínez-Buján Pérez ${ }^{54}$, es preciso aclarar cuál es la noción de normativización a que aludimos. Porque ésta puede estar referida tanto a los elementos del dolo, como a la fase previa de la fundamentación de la mayor gravedad de la sanción en los casos de comportamiento doloso.

La normativización en el fundamento de la sanción aparece como un concepto opuesto al de la perspectiva ontológica, e implica, básicamente, asumir criterios teleológicos — razones de índole valorativa, sociales y jurídicas, que atienden al sentido y al fin del Derecho penal — para afirmar la mayor severidad de la respuesta penal del delito doloso frente al imprudente. En general, es la postura dominante en las modernas teorías del dolo, una vez abandonada la idea finalista que basaba sus valoraciones en la peculiar estructura del comportamiento humano.

En esta línea podemos incluir, a vía ejemplar, la posición del profesor Mir Puig ${ }^{55}$, quien enmarca su posición en la idea de que la exigencia de dolo típico ha de relacionarse con la protección de bienes jurídico-penales, además de derivar del principio de culpabilidad. Luego, a la hora de diferenciar el dolo y la culpa, parte del dato fáctico para enjuiciarlo valorativamente: la distinta estructura fáctica del dolo y la culpa determina una diferencia que considera valorativamente relevante. En concreto, porque la voluntariedad del comportamiento dañoso en el hecho doloso supone una oposición al bien jurídico más intensa, que incide en el significado simbólico de la conducta que niega el bien lesionado, así como en su mayor peligrosidad objetiva $\wedge^{6}$. 


\begin{abstract}
A mayor abundamiento, en el ámbito del Derecho penal económico se suma otro problema, pues es muy difícil que al cometer el delito los actores económicos cuenten con un conocimiento actual sobre las distintas repercusiones de su hecho, debido a varias razones: la complejidad de la economía, los fenómenos de división del trabajo en los distintos ámbitos económicos o empresariales, la abstracción de los bienes jurídicamente protegidos, etc. Cfr. García Cavero, R, Derecho penal económico. Parte general, 2" ed., Grijley, Lima, 2007, p. 481. Martínez-Buján Pérez, Derecho penal económico y de la empresa, p. 355 y ss. Mir Puig, "Límites al normativismo en Derecho penal", p. 18:20. Posición que, sin embargo, se muestra especialmente débil a la hora de enjuiciar el dolo eventual, que en general
\end{abstract}

68 Revista Ius et Praxis - año $14-\mathrm{n}^{\circ} 1$

El delito de receptación aduanera y la normativización del dolo

La perspectiva normativa referida a los elementos del dolo, en tanto, se opone a la concepción psicológica del mismo. Su rasgo básico consiste en "concebir la realidad no como algo empírico (perceptible directamente a través de los métodos de investigación propios de las ciencias de la naturaleza) sino como una realidad valoradd^1.

Entre los autores que se autopostulan como normativistas, sólo algunos parecen serlo en este extremo. Entre ellos y avía ejemplar, destacaremos brevemente dos modelos que, aunque parten de presupuestos metodológicos diversos y plantean conceptos también disímiles, en la práctica terminan resultando básicamente coincidentes.

El primero es el que propone Vives Antón ${ }^{58}$, a partir de la concepción significativa de la acción que él mismo ha desarrollado. Previamente, hay que aclarar que cuando este autor alude a la intención se refiere a la atribución de intenciones al sujeto, cuestión que no desempeña un papel definitorio en la delimitación conceptual de la acción pero permite enjuiciar la conducta realizada. Esa intención forma un todo con la acción, porque ella alude a su sentido; mejor, la intención se expresa en la acción. Pero no debe suponerse que esta conexión intencional se produzca en el interior del sujeto, en su mente, sino que ella se establece en el medio público, pues sólo cobra sentido en el contexto público a través de reglas sociales, de modo que presupone una competencia ${ }^{59}$. Entonces, las reglas sociales permiten identificar y conocer la intención, y en la relación entre el autor y la acción, es a través del significado de sus actos, de las competencias que cabe atribuirle y del entramado de los estados intencionales que se plasman en su vida, que le imputamos —o no- una determinada intención ${ }^{60}$.

es sancionado con la misma pena que el dolo directo a pesar de que no podría ser valorado igual que aquel de conformidad con los criterios propuestos.

Martínez-Buján Pérez, Derecho penal económico y de la empresa, p. 356 (destacado en el original). Vives Antón, T., Fundamentos del sistema penal, Tirant lo Blanch, Valencia, 1996, p. 235 y ss., que construye su sistema sobre la base de la filosofía de la acción y del lenguaje, particularmente de Wittgenstein, sistema que paulatinamente va ganando más adeptos en España. En particular, adhiere a éste Martínez-Buján Pérez, Derecho penal económico y de la empresa, pp. 346-383, quien además desarrolla sus ideas y las sitúa en el entorno de la discusión dogmática actual, destacando que coinciden con su concepto de dolo autores como Díaz Pita, "La presunta inexistencia del elemento volitivo en el dolo y su imposibilidad de normativización", en Revista penal, N 17, 2006, p. 59 y ss.; Górriz Royo, Proyecto docente e investigador (inédito), Castellón, 2005, pp. 376 y 377; Pérez Alonso, en Zugaldía (dir.)/PÉREZ Alonso (coord.), Derecho penal. Parte general, Valencia, 2004, p. 507. Vives Antón, Fundamentos del sistema penal, p. 222, lo propone como corolario de la concepción contextual de la mente trazada por Wittgenstein. Vives Antón, Fundamentos del sistema penal, p. 233.

Revista Ius et Praxis - año 14 - nº 169

Magdalena Ossandon Widow

Según Vives Antón el dolo consiste en la manifestación de un compromiso de actuar del autor, que consta tanto de un elemento cognitivo como de uno volitivo. Ambos elementos son concebidos de modo normativo, pues se determinan con independencia de los inverificables procesos mentales que se experimenten en el fondo del alma del autor.

Así, para atribuir una conducta dolosa, es necesario, en primer lugar, fijar las reglas sociales y jurídicas que definen la acción como acción típica, y, en seguida, relacionar tales reglas con el bagaje de conocimientos o la competencia del autor para, desde un punto de vista externo, poder afirmar qué es lo que el autor sabía ${ }^{61}$. Por ende, lo que el autor sabe no es lo que se ha representado o lo que ha previsto en su mente, sino su bagaje intelectual, las técnicas que domina. Esta es una cuestión que se determina de modo fáctico, según los datos concurrentes al momento de la realización del hecho.

Pero afirmar que el sujeto conoce, es decir, que cuenta con los datos para adoptar una determinada decisión, no es todavía suficiente. Porque la imputación dolosa requiere un grado de voluntad, también en sentido normativo, que supone un compromiso con el significado de su conducta (significado que consiste, concretamente, en la vulneración del bien jurídico). Entonces, es necesario acreditar que el sujeto, entre diversas alternativas de actuación, ha seleccionado la decisión contraria al bien jurídico, una decisión especial, de enfrentamiento con la sociedad, porque ésta había calificado dicho bien como valioso para la convivencia al protegerlo penalmente. Esa decisión se pone de manifiesto o se deduce de la situación concreta y del significado externo de ese comportamiento.

Sólo concurriendo todos estos elementos se puede imputar dolo, sea directo o eventual, pues en ambos cabe afirmar que el sujeto ha actuado intencionalmente. 
En ejemplos proporcionados por el propio Vives Antón ${ }^{62}$ : "el jugador que apuesta a la ruleta puede estar tan seguro como se quiera de que ganará; puede entrar en el juego sin haberse representado, ni por un momento, que podía perder; puede confiar en su estrella hasta el punto de no haber hecho ningún cálculo. Sin embargo, si sabe lo que es unjuego, si domina la técnica de la ruleta, ha de saber, también, que puede perder y que, excepto dejar de jugar, no tiene ningún medio para evitar que el hecho de perder suceda; de modo que, si juega, se halla

\footnotetext{
Vives Antón, Fundamentos del sistema penal, p. 233; asume aquí también la idea de Wittgenstein, Investigaciones filosóficas, §199, cuando afirma que entender un lenguaje significa dominar una técnica (saber usar los signos convencionales e instrumentales que constituyen el lenguaje); gramática de la palabra entender que se
} relaciona también estrechamente con la de conocer. Vives Antón, Fundamentos del sistema penal, pp. 240 y 241.

70 Revista Ius et Praxis - año $14-n^{\circ} 1$

El delito de receptación aduanera y la normativización del dolo

comprometido con la posibilidad de perder: esa posibilidad (perder) forma parte de su intención. Del mismo modo, el conductor suicida que, por apuesta o simplemente por afán de riesgo, marcha a toda velocidad por la parte izquierda de la calzada, si conoce la circulación y sabe lo que es conducir, ha de aceptar que, al actuar así, contrae un compromiso con el accidente letal que causa: tenía, sin duda, una (eventual) intención de matar"; pero aclara que "el médico que, tratando de acudir con urgencia al lugar donde un paciente precisa un tratamiento sin cuya rápida administración morirá, conduce un tramo por la izquierda para evitar un largo rodeo (...) no puede decirse, si ocasiona un accidente mortal, que tuviera la intención de hacerlo, esto es que se halla comprometido con su causación. Aquí, la acción que arrastra el peligro no conlleva una intención de matar, pese que exista el dominio de la técnica de que se trata (conducir) y, por consiguiente, el conocimiento del resultado... pues el compromiso, en que la intención consiste, comporta un componente normativo, que en el caso del médico, desde luego no concurre".

Un segundo concepto normativo de dolo es el que formula Ragúes i Valles. Su tesis se basa en el sentido social como criterio de determinación del conocimiento exigido por el dolo, en el marco de una concepción comunicativa del Derecho penal. Considera que la finalidad de la pena en los delitos dolosos es la de replicar a aquellos hechos que, desde una perspectiva social, transmiten a la colectividad un mensaje de negación de una norma penal. En otras palabras, la pena sirve para reafirmar la vigencia de la norma. Entonces, en la misma línea, ha de valorarse como consciente — dolosoaquel hecho que también lo es desde la óptica de los destinatarios del mensaje que incorpora la sanción penal ${ }^{63}$. "Las personas, en tanto que miembros de una misma sociedad en constante proceso de comunicación, comparten una serie de valoraciones de acuerdo con las cuales entienden que, dadas determinadas realidades objetivas, otro sujeto cuenta de forma inequívoca con ciertos conocimientos" 64 . Esas valoraciones, concretadas en reglas de atribución, deben ser también el criterio a utilizar para determinar los conocimientos del autor y, así, permitir una sanción por delito doloso.

Prescindiendo del elemento volitivo, concluye que "existe dolo cuando, a partir del sentido social de un hecho y de las circunstancias que lo acompañan, puede afirmarse de modo inequívoco que un sujeto ha llevado a cabo un comportamiento objetivamente típico atribuyéndole la concreta capacidad de realizar un tipo penal"65. Es decir, el dolo se configura al realizar un juicio de atribución del conocimiento, juicio que proviene de una comprensión intersubjetiva

Ragúes i Valles, El dolo y su prueba en el proceso penal, pp. 323-324, aludiendo directamente a Jakobs, G.,

Derecho penal. Parte general. Fundamentos y teoría de la imputación (trad. Cuello Contreras/Serrano González

de Murillo), Marcial Pons, Madrid, 1995, p. 12 y ss.

Ragúes i Valles, El dolo y su prueba en el proceso penal, p. 358.

Ragúes i Valles, El dolo y su prueba en el proceso penal, p. 353.

Revista Ius et Praxis - año 14 - n 171

Magdalena Ossandon Widow

de la realidad por quienes forman parte de la sociedad, basado en reglas sociales de imputación o atribución de conocimientos.

Ahora bien, admite este autor que una condena basada en el sentido social del hecho implica siempre un cierto margen de error, pues no es posible garantizar que los criterios que la sociedad emplea para decidir cuándo un hecho ha sido realizado conscientemente coincidan siempre con los auténticos conocimientos del sujeto, ni, por tanto, que éste haya podido evitar ser condenado por un delito doloso. Existe, entonces, el riesgo de que con la sanción penal se esté instrumentalizando al condenado. Pero el criterio sigue siendo legítimo si se 
considera que todo sujeto que pretende ser protegido por el Derecho penal está dispuesto a asumir el (escaso) riesgo de ser alguna vez condenado sin haber contado (desde el punto de vista psicológico) con los conocimientos requeridos por el dolo ${ }^{66}$.

Por otra parte, reconoce también que la idea del sentido social resulta por sí sola demasiado vaga y, por eso, está expuesta al peligro de un empleo arbitrario. Pero frente a ello plantea la necesidad de desarrollar criterios más concretos para determinar en qué casos, a partir del sentido social de una conducta, puede afirmarse de modo inequívoco que ésta ha sido realizada con el conocimiento requerido por el dolo ${ }^{67}$. Criterios que el mismo autor desarrolla en la tercera parte de su trabajo: conocimientos mínimos, transmisiones previas de conocimientos, exteriorización del propio conocimiento, características personales del sujeto, distinción entre conductas especialmente aptas para producir un resultado lesivo y otras neutras desde ese punto de vista, etc ${ }^{68}$.

Como se advierte, la gran diferencia con la concepción anterior es que la de Ragúes i Valles es una tesis puramente cognitiva, en que no se exige una voluntad o decisión contraria al bien jurídico. Con todo, los criterios de atribución de conocimiento propuestos, en la práctica, coinciden con los que se emplean para acreditar la existencia de dicha voluntad y constatar el compromiso con la vulneración del bien jurídico a que se refiere Vives Antón ${ }^{69}$, de modo que

\footnotetext{
Para que este riesgo resulte soportable por los ciudadanos, el recurso a la sanción penal debe quedar sometido a ciertas condiciones. La principal, que se de una situación de igualdad entre los posibles destinatarios de los riesgos inherentes a la existencia del Derecho penal. Ello implica que no pueda determinarse a priori qué concretos

individuos van a padecer la existencia de tales riesgos y que los criterios que se usen para determinar tal padecimiento garanticen un trato igualitario entre todos los posibles destinatarios. Y, en segundo lugar, que se asuman sólo aquellos riesgos que resulten imprescindibles para garantizar la razón de ser del Derecho penal. Ragúes i V allés, El dolo y su prueba en el proceso penal, pp. 344 y 352. Ragúes i Valles, El dolo y su prueba en el proceso penal, p. 348. Criterios que propone y desarrolla en los capítulos XII a XVII de su obra. Así lo destaca Martínez-Buján Pérez, Derecho penal económico y de la empresa, p. 368.
}

72 Revista Ius et Praxis - año $14-n^{\circ} 1$

El delito de receptación aduanera y la normativización del dolo

ambas posiciones se acercan considerablemente. Sin embargo, en la perspectiva teórica, coincidimos más bien con el planteamiento meramente cognitivo, en cuanto resulta más acorde con la visión actual del Derecho penal como encargado de evitar la creación de riesgos prohibidos más que de proteger bienes jurídicos frente a ataques dirigidos a lesionarlos ${ }^{70}$.

Pero más que profundizar en los diferentes conceptos que se pueden plantear desde esta perspectiva normativa, lo que hemos pretendido con su exposición es confirmar la posibilidad de concebir el dolo desde una perspectiva estrictamente normativa, y destacar la idea matriz que sustenta estas posiciones. Esto es, que el dolo, como todos los elementos de la imputación jurídico-penal, no es un concepto descriptivo, sino adscriptivo. Esto significa que, en estricto rigor, el dolo no se constata sino que se atribuye ${ }^{71}$.

Concordamos con las tesis expuestas en que los criterios de atribución del dolo giran en torno a las reglas sociales, al sentido social de la conducta, en la medida en que éste es asumido por el Derecho penal. Esto quiere decir que la atribución del dolo se rige según los parámetros establecidos en el ordenamiento jurídico-penal, los que se deben ${ }^{12}$ determinar a partir de la estructura social y del conjunto de expectativas que se dirigen al detentador de una determinada posición. Esto es lo que se denomina rol social, entendido como un haz de expectativas sociales, expectativas que, a su vez, se expresan en forma de normas ${ }^{73}$.

La idea de rol, por ende, no sólo sirve para imputar objetivamente un comportamiento, sino también desde el punto de vista subjetivo. Ya hemos visto que el acceso a la interioridad de una persona es tan imposible como, en gran medida, ajeno a los fines de la imputación jurídico-penal; por lo tanto, la determinación de la faceta interna del hecho debe hacerse mediante datos 
Revista Ius et Praxis - año 14 - nº 173

Magdalena Ossandon Widow

objetivos socialmente comprensibles. Más aún, como agrega García Cavero, "no se trata de una verificación de la interioridad mediante datos objetivos, sino de una imputación realizada con base en criterios jurídico-penales. Esos criterios jurídico-penales deben determinarse a partir de una evitabilidad individual exigida por los roles atribuidos al ciudadano"74.

En definitiva, la imputación subjetiva no se construye a partir del conocimiento actual del sujeto al momento de cometer el hecho, sino del conocimiento que le es exigible al autor por el rol que cumple en ese momento ${ }^{75}$. Por lo mismo, no se debe interpretar el concepto normativo como una especie de mecanismo para, en el fondo, presumir el dolo. Ello no es necesario porque, desde este punto de vista, el nivel de conocimiento real del infractor no es relevante; lo que importa es la posibilidad de imputar responsabilidad, en la medida en que el conocimiento fuera exigible ${ }^{76}$.

Obviamente que los criterios de atribución de dolo no pueden desconocer la realidad social y personal en que se enmarca la conducta — pues el funcionamiento del sistema penal así lo requiere — y, por lo mismo, en la práctica la imputación subjetiva va a coincidir, con absoluta frecuencia, con lo que efectivamente ocurre en la interioridad del sujeto. Pero lo que debe quedar claro es que esa imputación jurídico-penal no se fundamenta en la comprobación empírica de una actitud psicológica. "Que al momento del hecho el autor sea consciente o no de que lesiona un objeto socialmente valioso tiene muy poca importancia para la imputación subjetiva. La imputación subjetiva se determina, más bien, mediante las competencias de conocimiento derivadas del rol, atendiendo, claro está, a las circunstancias personales del autor"77.

García Cavero, Derecho penal económico. PG, p. 335-336.

Cfr. García Cavero, Derecho penal económico. PG, p. 336, apoyándose en las ideas de Jakobs, G., Sociedad, norma y persona en una teoría de un Derecho penal funcional (trad. Cancio Melía/Feijóo Sánchez), Civitas, Madrid, 1996, p. 55.

En particular, Ragúes i Valles, El dolo y su prueba en el proceso penal, pp. 345-346, diferencia el sistema de atribución del conocimiento del de presunciones, en que el primero no prejuzga un hecho antes de entrar en su análisis. Es verdad que al realizar el análisis deben aplicarse reglas con carácter presuntivo - detrás de la significación social se ocultan determinadas presunciones asentadas en las valoraciones sociales, que permiten entender que el autor ha actuado con determinados conocimientos-; y es que "el contenido presuntivo es inevitable en todo juicio de atribución del conocimiento que no pase por un plena reconstrucción de éste como proceso psíquico

efectivamente acaecido". Pero, a diferencia de las presunciones que reducen los criterios de atribución a una única regla, el sentido social reconoce la riqueza y variedad de los comportamientos humanos, y, además, supone una valoración del hecho a partir de datos objetivos previamente probados, por lo que no hace recaer la carga de la prueba del tipo subjetivo en el acusado, sino que ofrece una valoración que en determinados casos puede beneficiarle. García Cavero, Derecho penal económico. PG, p. 336.

74 Revista Ius et Praxis - año $14-n^{\circ} 1$

El delito de receptación aduanera y la normativización del dolo

En el fondo, debemos concluir que el problema del dolo es, en gran medida, un problema (normativo) de exigibilidad ${ }^{78}$. "La atribución del dolo es, por ello, una parte de la respuesta a la pregunta acerca del nivel de conocimientos que es razonable exigir de un ciudadano en la situación del autor, de acuerdo a los criterios de distribución de responsabilidades y riesgos vigentes en la sociedad"79.

Puede criticarse esta conclusión porque implica una cierta confusión de categorías dentro de la teoría del delito. Pues, en general, se comienza analizando el dolo dentro de la tipicidad, para terminar afirmando que bajo él subyace un problema de exigibilidad $^{80}$. Lo cierto es que esta es una crítica a la que normalmente se ha visto expuesto el funcionalismo jurídicopenal, frente a la cual sólo queda reconocer que aunque tenga algo de verdad, una construcción funcional del sistema no puede verse condicionada por las estructuras tradicionalmente empleadas para describirlo. Es más, aunque las corrientes funcionalistas no han pretendido, en principio, una modificación del sistema de la teoría del delito, no puede descartase que ellas impliquen una modificación sistemática en diversos ámbitos de dicha teoría ${ }^{81}$. Por ejemplo, de lo dispuesto en el art. $110 \mathrm{CT}$ y el art. $10 \mathrm{~N}^{\circ} 12 \mathrm{CP}$, Van Weezel concluye que "es posible observar la estrecha relación que existe entre la normalidad o anormalidad de la motivación (insuperabilidad de la causa) y el error sobre el alcance de las normas tributarias, pues pone de manifiesto que el problema de la vencibilidad o invencibilidad del error es en definitiva un problema de exigibilidad, y que por lo mismo no es adecuado dividir sistemáticamente (otra cosa puede valer a efectos didácticos) el lado subjetivo del hecho entre faz subjetiva del tipo penal y culpabilidad"82.

Cfr. Van Weezel, Delitos tributarios, p. 45.

Van Weezel, Delitos tributarios, p. 64. Es un juicio individual, considerando la situación del autor, porque no se trata de una evitabilidad general, sino de una evitabilidad individual, cfr. García C avero, Derecho penal económico. PG, p. 336.

Así, por ejemplo, Ortiz Quiroga, L., "Recensión: Van Weezel, Alex. Delitos Tributarios. Editorial Jurídica de Chile, 2007, 206 páginas", en Política Criminal N 4, 2007, Rl, p. 1-5 [http://www.politicacriminal.cl], p. 3, quien defiende un concepto de dolo dentro de la culpabilidad y no en el tipo, para cumplir con lo que el texto de nuestra ley señala al identificar el dolo con la malicia, se alegra al advertir que el autor que comenta pareciera, por vertientes distintas, coincidir en parte con este planteamiento, "pues 


\begin{abstract}
defiende un concepto adscriptivo del dolo que evidencia a través de un fallo donde se enumeran las distintas circunstancias que el tribunal ha tomado en consideración. Todas ellas son claros indicadores de conocimiento del injusto por parte del autor, que llevaron a calificar como doloso el comportamiento del contribuyente al omitir
\end{abstract} facturas en la declaración al Impuesto al Valor Agregado".

En este sentido, lo advertía tempranamente Silva Sánchez, "Evolución de la dogmática del Derecho penal en Alemania", p. 271. Van Weezel, Delitos tributarios, p. 45.

Revista Ius et Praxis - año $14-n^{\circ} 175$

Magdalena Ossandon Widow

\title{
VIL Repercusiones de una concepción normativa de dolo
}

Que la opción por un concepto psicológico o normativo del dolo no es una mera disquisición teórica, ya lo hemos advertido al analizar uno de los motivos para abandonar el criterio tradicional. Esto es, la imposibilidad de tener por acreditado el fenómeno psicológico en que se apoya, problema probatorio que haría prácticamente imposible sancionar a alguien por un delito doloso si se quiere ser realmente consecuente con los principios limitadores del Derecho penal.

Pero también existen otras consecuencias de orden práctico que interesan especialmente en el ámbito de los delitos de receptación que han motivado estas consideraciones.

\section{a) La posición del autor en el sistema económico}

Afirmar que el dolo se atribuye con base en las competencias de conocimiento que cada rol impone a su titular - a lo que se debe añadir la posibilidad concreta de alcanzar esos conocimientos en las circunstancias concretas, para que la imputación sea personalizada ${ }^{83}$ - , hace decisivo reparar en el rol que, por lo general, desempeñan los autores de los delitos de receptación y de receptación aduanera en particular. En efecto, ya al comenzar estas reflexiones ubicamos el delito de receptación en un contexto económico, aún cuando no pueda afirmarse que el orden público económico sea el bien jurídico protegido por la figura. En ese contexto, quienes actúan generalmente son personas dedicadas a la actividad económica en sus diferentes facetas (empresarios, comerciantes, transportistas, contadores, etc.). Esa posición especial del autor en el sistema económico permite imputarle más fácilmente el conocimiento exigido por el tipo, esto es, el del origen delictivo de las mercancías ${ }^{84}$.

Las características personales del sujeto, entre las que destaca su profesión y estudios, sus relaciones con otros individuos, su actividad habitual, etc., siempre han sido, ya en la práctica social, una importante base objetiva para que le puedan ser atribuidos ciertos conocimientos. No es de extrañar, por tanto, que asuman un papel determinante también en el proceso de imputación subjetiva ${ }^{85}$.

Lo vuelve a destacar García Cavero, Derecho penal económico. PG, p. 485.

Más todavía, aun cuando se acredite que tenía dudas sobre ese punto, puede afirmarse que "si el sujeto económico debía conocer el carácter prohibido de su hecho en razón del ámbito en el que se desenvuelve y este conocimiento le resultaba accesible desde sus circunstancias personales, entonces una situación de duda interna no tendrá ninguna relevancia normativa", García Cavero, Derecho penal económico. PG, p. 515. Ellas son propuestas como un criterio fundamental de atribución de conocimientos por Ragúes i Valles, El dolo y

76 Revista Ius et Praxis - año $14-\mathrm{n}^{\circ} 1$

El delito de receptación aduanera y la normativización del dolo

No se quiere afirmar con esto que, por ejemplo, cualquier comerciante, por el sólo hecho de serlo y de tener en su poder mercancías nuevas extranjeras destinadas a la venta, pueda ser condenado como autor de un delito doloso de receptación. Porque la atribución de dolo tiene que ser inequívoca e individual, y eso implica reconocer varias limitaciones en este proceso. Por ejemplo, que "sólo deben imputarse a un sujeto aquellos conocimientos que vayan intrínsecamente ligados al hecho de reunir unas determinadas características personales, es decir, aquellos conocimientos sin los que sería impensable que pudiera reunir tales características" 86 . En el mismo sentido, no basta con establecer formalmente las características personales que reunía el sujeto al momento del hecho, sino que hay que contextualizarlas atendiendo al modo concreto en que se han ejercido las posiciones sociales del individuo. Tampoco puede negarse valor a los actos de delegación, que generalmente operan al aumentar la complejidad o las dimensiones de un negocio o empresa, lo que 
significa que no se puede imputar el conocimiento de todo lo que tenga que ver con el funcionamiento de la estructura que dirige a quien se encuentra en lo más alto de una pirámide organizativa, sólo por ocupar tal posición ${ }^{87}$.

Así, por ejemplo, no basta con ser dueño de una empresa de transporte, si ella es completamente administrada por otro ${ }^{88}$; ni se le puede atribuir el conocimiento de lo que transportaba a todo chofer de un camión transportista, cuando la práctica en la empresa era que a éste se le negaba acceso a toda información sobre la $\operatorname{carga}^{89}$.

\section{b) La diferencia entre dolo directo, dolo eventual y culpa}

La perspectiva normativa conduce a que la diferencia entre las diversas clases de dolo, así como entre el dolo y la culpa —que no puede construirse sobre labase de una diversa actitud psico-

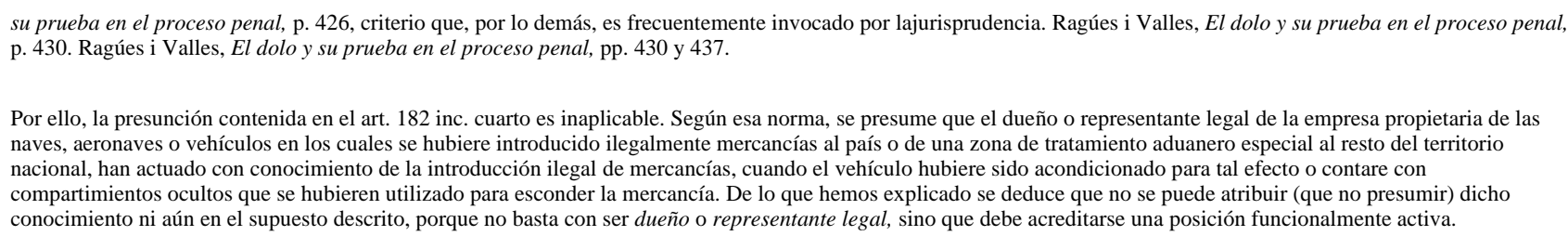

Por ello, la presunción contenida en el art. 182 inc. cuarto es inaplicable. Según esa norma, se presume que el dueño o representante legal de la empresa propietaria de las naves, aeronaves o vehículos en los cuales se hubiere introducido ilegalmente mercancías al país o de una zona de tratamiento aduanero especial al resto del territorio nacional, han actuado con conocimiento de la introducción ilegal de mercancías, cuando el vehículo hubiere sido acondicionado para tal efecto o contare con compartimientos ocultos que se hubieren utilizado para esconder la mercancía. De lo que hemos explicado se deduce que no se puede atribuir (que no presumir) dicho conocimiento ni aún en el supuesto descrito, porque no basta con ser dueño o representante legal, sino que debe acreditarse una posición funcionalmente activa.

No debe interpretarse en otro sentido el art. 171 OA cuando dispone que "los conductores de cualquier vehículo procedente del extranj ero, responderán personalmente de las multas que se les impongan, aunque la Aduana para hacer efectivo el cobro pueda dirigir su acción contra la empresa de transporte o los consignatarios del vehículo", pues esta norma sólo puede referirse a una responsabilidad administrativa, no penal.

Revista Ius et Praxis - año $14-n^{\circ} 177$

Magdalena Ossandon Widow

lógica—, deba considerarse una cuestión valorativo cuantitativa ${ }^{90}$. En el fondo, el asunto no pasa por identificar un determinado objeto (un dolo directo o un dolo eventual) sino que es un problema de dilucidar la gravedad de actitudes antinormativas, utilizando criterios de comprensión ${ }^{91}$.

De esta forma, por lo demás, el concepto de imprudencia pasa a tener una simetría con el de dolo, pues ambos responden a un juicio normativo ${ }^{92}$; mientras que desde la postura tradicional psicológica sólo la culpa se considera de ese modo.

Ahora bien, es evidente que el criterio para medir esa diversa intensidad que marca el paso de un título de imputación a otro variará dependiendo de la forma como se haya definido el dolo.

Por ejemplo, en el marco de la concepción significativa de la acción de Vives Antón, la diferencia entre dolo directo y eventual se fija con base en la mayor o menor intensidad del compromiso con la vulneración del bien jurídico que revela la conducta antinormativa. Mayor intensidad que, a su vez, comporta una decisión contraria al bien jurídico más evidente $^{93}$. Para estos efectos, que el conocimiento del autor sea seguro o inseguro no constituye más que un indicador de la gravedad de la infracción, pero no es un criterio definitivo. Por su parte, la imprudencia se caracteriza por una doble ausencia de compromiso, el que no existe ni respecto del resultado típico ni respecto de la evitación de la lesión ${ }^{94}$. Más precisamente, la diferencia entre dolo eventual y culpa inconsciente estaba en que en esta última existe un absoluto desconocimiento de la peligrosidad de la conducta en relación con un hecho típico o un error vencible sobre algún elemento típico; mientras que se distingue de la culpa consciente, en virtud la existencia o inexistencia de un elemento volitivo plasmado en el compromiso con la vulneración del bien jurídico ${ }^{95}$.

Para las tesis puramente cognitivas, la diferencia radica en la clase de conocimiento que tiene o, más bien, que se le imputa al autor del hecho. El sujeto que actúa dolosamente es el que conoce el significado típico de la conducta que realiza, mientras que el sujeto imprudente

Cfr. García Cavero, Derecho penal económico. PG, p. 477.

Cfr. Vives Antón, Fundamentos del sistema penal, p. 238 y ss.

Martínez-Buján Pérez, Derecho penal económico y de la empresa, p. 384, y Vives Antón, Fundamentos del

sistema penal, p. 244. 


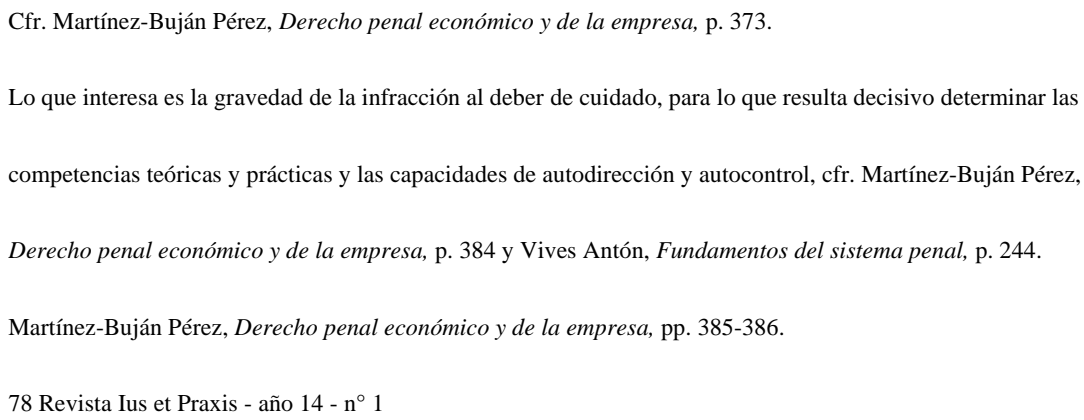

El delito de receptación aduanera y la normativización del dolo

desconoce en toda su dimensión ese significado ${ }^{96}$. Se trata, entonces, de diversos niveles de conocimiento a la hora de tomar la decisión; en el primer caso el sujeto cuenta con información suficiente sobre el alcance de la acción; en el segundo, se le atribuyen datos equivocados o un cálculo erróneo, es decir, un defecto cognitivo frente al cual la reacción penal puede ser de menor intensidad. Porque, como bien explica Ragúes i Valles, en el caso del delito doloso, "el sujeto expresa con su conducta el sentido social de negación de la vigencia de una norma penal: la norma afirma, por ejemplo, «no se puede matar» y el sujeto replica con su hecho que «sí se puede matar». Por contra, la estructura propia de las comisiones imprudentes resulta bien distinta: la norma afirma «no se puede matar» y el sujeto replica «yo no estoy matando»"97. Lo primero ocurre siempre que el individuo atribuya a su concreta conducta la capacidad de producir ese resultado, cualquiera sea su posición anímica frente al mismo.

García Cavero precisa estas ideas, al afirmar que si el nivel de conocimiento atribuido al autor sobre la defraudación de la norma obligaría a un ciudadano fiel al Derecho a desistir de su actuación riesgosa o a interrumpir un suceso riesgoso, se tratará de un delito doloso. Si el nivel de conocimiento resulta insuficiente para activar este deber — lo que sucedería cuando no alcanza para atribuir a la conducta la aptitud lesiva-, pero esta insuficiencia se hubiese vencido de haberse cumplido con ciertos deberes de cuidado, estaremos ante un delito culposo ${ }^{98}$. En el fondo, en la culpa se imputa un conocimiento de menor grado que, unido a criterios normativos, permite afirmar la posibilidad de haber conocido la realización del tipo penal (cognoscibilidad).

No pretendemos profundizar más en una cuestión de tan insondables dimensiones, pero lo expuesto sirve al menos para esbozar las diferencias entre estas categorías de imputación y justificar que un concepto normativo de dolo está en condiciones de explicar adecuadamente, desde el punto de vista de la finalidad del Derecho penal, por qué los hechos dolosos merecen una mayor pena que los culposos. En el fondo, el criterio teleológico condiciona la definición del dolo y la culpa, lo que, a su vez, se refleja en su diversa valoración penológica.

En este sentido, Silva Sánchez, J. M., Aproximación al Derecho penal contemporáneo, Bosch, Barcelona, 1992, p. 401.

Ragúes i Valles, El dolo y su prueba en el proceso penal, p. 167.

García Cavero, Derecho penal económico. $P G$, pp. 477-478, 560 y ss. La delimitación debe hacerse desde el punto de vista del deber específico
que surge por el conocimiento imputable al autor: un deber de desistir o interrumpir la actuación riesgosa (dolo), o seguir actuando que surge por el conocimiento imputable al autor:
observando ciertos deberes de cuidado (culpa).

Revista Ius et Praxis - año 14 - n 179

Magdalena Ossandon Widow

\section{c) La punibilidad de la ignorancia deliberada}

Por último, nos interesa destacar que desde un enfoque normativo se resuelve mejor el problema de las hipótesis — normalmente encuadradas como "casos límite"_ de ignorancia deliberada o de gravísimo desprecio por los bienes jurídicos, en los cuales el autor es completamente indiferente al riesgo que provoca o ni siquiera se lo plantea. Porque la ausencia de conocimiento efectivo no impide la imputación a título de dolo (eventual) ${ }^{99}$.

Aunque este es un tópico que no se ha planteado mayormente en nuestro país, sí se está ganando un lugar en la dogmática e, incluso, en la jurisprudencia de países de tradición continental ${ }^{100}$. Se conecta también, aunque con ciertos matices de diferencia, con la doctrina de la willful blindness del derecho anglosajón ${ }^{101}$.

Lo novedoso del tema hace que todavía no esté del todo definido qué es exactamente lo que se entiende con expresiones como ignorancia deliberada o intencional, desconocimiento provocado, etc. De hecho, no pocas veces se alude con ellas 
a supuestos que bien podrían recon-ducirse al dolo eventual. Por ejemplo, casos de narcotráfico en que el imputado niega conocer la clase o cantidad de droga de que se trataba (para evitar la aplicación de un tipo agravado), o de un sujeto que proporciona cierta información a miembros de un grupo terrorista y luego alega que no conocía cuál era el fin de la información solicitada, etc. En general, supuestos en que el hecho y sus circunstancias generarían fundadas sospechas de delito para cualquier persona, y no resulta creíble una disculpa en sentido contrario; entonces, bien puede decirse de quien omite tomar medidas para no cometer el tipo penal, que obra con una indiferencia constitutiva de dolo eventual, porque ante la posibilidad innegable de realizar un delito, de todas maneras ha obrado.

Pero también pueden imaginarse situaciones en que la alegación de desconocimiento resulte verosímil, es decir, en que la prueba — por indicios, obviamente- lleve al tribunal a en-

Incluso a partir de la la concepción significativa de la acción propuesta por Vives Antón, en que basta con acreditar, por las circunstancias del caso y por medio de una fundamentación normativa, que existe el compromiso con la vulneración del bien jurídico. Cfr, Martínez-Buján Pérez, Derecho penal económico y de la empresa, p. 350.

Da cuenta de esta realidad en la jurisprudencia del Tribunal Supremo español, que a partir del año 2000 invoca este concepto en numerosos fallos y apela como referente a la figura de la willful blindness norteamericana, Ragúes i Valles, R., La ignorancia deliberada en Derecho penal, Atelier, Barcelona, 2007, p. 22-26. En ese modelo lleva al menos una centuria de ventaja; en Inglaterra es doctrina asentada desde fines del siglo XIX. En esa época comienza a ser invocada en Estados Unidos, en que para la década de 1970 ya se aplica generalizadamente en casos de narcotráfico; cfr. con referencias Ragúes i Valles, La ignorancia deliberada en Derecho penal, pp. 66-67 y 69.

80 Revista Ius et Praxis - año 14 - n 1

El delito de receptación aduanera y la normativización del dolo

juiciar el caso a partir de la base de un verdadero desconocimiento, aunque este sea provocado. Estaríamos entonces ante un caso de ignorancia deliberada que para efectos de la imputación penal es definida por Ragúes i Valles como la situación de todo aquel que "pudiendo y debiendo conocer determinadas circunstancias penalmente relevantes de su conducta, toma deliberada o conscientemente la decisión de mantenerse en la ignorancia con respecto de ellas"102. En relación con los delitos de receptación, ésta es una situación fácilmente imaginable, considerando que los eventuales imputados por este delito frecuentemente alegan haber desconocido el origen de las especies o mercancías que se encuentren en su poder, y podrían tomar medidas y aportar pruebas para confirmar esa ignorancia, haciéndola jugar en su favor.

La cuestión, en estos casos, es determinar el tratamiento penológico que corresponde, esto es, decidir si situaciones de desconocimiento respecto de los elementos del tipo merecen ser calificadas como culpa o si pueden llegar a configurar un delito doloso.

Si sostuviéramos un concepto psicológico de dolo, la solución sería, inevitablemente, la del delito culposo. Sin embargo, esa solución resulta criticable desde un punto de vista axio-lógico, pues parece innegable que al menos ciertos supuestos de ignorancia merecen una respuesta más severa que la prevista para la mera imprudencia y, en todo caso, no deberían resultar impunes respecto de tantos delitos en que ni siquiera se prevé el castigo de la modalidad culposa ${ }^{103}$. Incluso puede cuestionarse el diverso tratamiento que, de este modo, se asigna al desconocimiento de los elementos del tipo — ceguera fáctica—, del que corresponde a la ignorancia sobre la antijuridicidad de la conducta — ceguera jurídica-, diferencia que propicia la teoría de la culpabilidad ampliamente dominante en la doctrina comparada. Sin embargo, no existirían razones sistemáticas ni valorativas que la justifiquen ${ }^{104}$.

Ragúes i Valles, La ignorancia deliberada en Derecho penal, p. 158. La fórmula que ha utilizado el Tribunal Supremo español para referirse a esta situación es la de que "quien no quiere saber aquello que puede y debe conocer, y sin embargo trata de beneficiarse de dicha situación, si es descubierto no puede alegar ignorancia alguna, y, por el contrario, debe responder de las consecuencias de su ilícito actuar", por todas, STS de 20 de marzo de 2003, ponente Giménez García.

Así, Ragúes i Valles, La ignorancia deliberada en Derecho penal, p. 122.

En este sentido, uno de los autores que se ha ocupado con mayor detenimiento de lo que considera un contrasentido de la legislación alemana que determina el dolo rígidamente según hechos psíquicos (conocimiento/desconocimiento), sin atender a los motivos, mientras que al referirse a la cognoscibilidad del injusto opta por una regulación elástica, es Jakob s, Derecho penal. PG, apdo. 8, número 5 y ss.; El mismo, Sociedad, norma y persona en una teoría de un Derecho penal funcional, p. 56-57; el mismo, "Sobre el tratamiento de los defectos volitivos y de los defectos cognitivos" (trad. Suárez González) en Estudios de Derecho penal, Civitas, Madrid, 1997, pp. 128-146, y el mismo, "Indiferencia como dolo indirecto" (trad. Pérez del Valle), en López de Quiroga/Zugaldía Espinar (coords.), Dogmática y ley penal. Libro homenaje a Enrique Bacigalupo, I, Marcial Pons, Madrid-Barcelona, 2004, pp. 345-358. Destaca esta incoherencia como una de las causas de la crisis de la teoría de la

Revista Ius et Praxis - año 14 - n 181

Magdalena Ossandon Widow

Sin entrar en cuáles son esas situaciones en que la indiferencia merece ser equiparada valorativamente al dolo ${ }^{105}$, 
aplicándole el mismo régimen o, por lo menos, un régimen diverso del que se dedica a los delitos culposos, queremos solamente destacar que la posibilidad de dicho tratamiento es perfectamente compatible con un concepto normativo de dolo. Esto, en la medida en que "el sujeto (económico) indiferente sigue siendo un ciudadano, de manera que le son atribuibles igualmente las competencias de conocimiento establecidas por el ordenamiento jurídico y la utilización de este conocimiento para determinar el carácter penalmente relevante de su hecho"106.

\section{El deber de presumir que las mercancías han sido o son objeto de un delito aduanero como normativización del dolo}

Formuladas todas estas consideraciones podemos volver al punto de partida, para concluir que el deber de presumir que las mercancías han sido o son objeto de un delito aduanero, al que se refiere el inciso primero del art. 182 O A, puede ser intepretado como una consagración expresa del concepto normativo de dolo.

En otras palabras, esta referencia no implica presumir cuáles eran los conocimientos que poseía el sujeto activo respecto del origen de las mercancías al momento del hecho, ni se refiere al modo de probar dichos conocimientos. Lo que dispone es que, cuando fuere exigible dicho conocimiento, se puede atribuir el dolo al autor de la conducta típica.

La misma interpretación defiende Van Weezel para el delito de receptación tipificado en el art. 456 bis A CP, en relación con la alusión que contiene a que el sujeto actúe "no pudiendo menos que conocerlo" (el origen de las especies). En su virtud, entiende este autor, "el simple desconocimiento no libera de responsabilidad, cuando nos parece que se trata de situaciones o elementos que el sujeto — no un hombre medio— no podía menos que conocer. Si no lo ha hecho, se le reprocha la falta de conocimiento como ceguera ante los hechos"107. El principio,

culpabilidad para el tratamiento del error Van Weezel, Delitos tributarios, p. 37.

Ragúes i Valles, La ignorancia deliberada en Derecho penal, p. 187, pone el acento en tres elementos que harían que la indiferencia deje el plano de lo culposo y entre a configurar un delito doloso: a) sospecha previa, b) persistencia de la decisión de desconocer y c) persecución de beneficios sin asunción de riesgos propios y evitación de responsabilidades. Para Jakobs, "Indiferencia como dolo indirecto", p. 355 y ss. ello ocurre cuando el sujeto indiferente frente a su conducta lesiva, se guarda de riesgos que puedan poner en juego sus propios intereses; de acuerdo, García Cavero, Derecho penal económico. PG, p. 517. García Cavero, Derecho penal económico. PG, p. 517. Van Weezel, Delitos tributarios, p. 62.

82 Revista Ius et Praxis - año $14-n^{\circ} 1$

El delito de receptación aduanera y la normativización del dolo

entonces, es que no todo desconocimiento debe ser considerado como un error que libera de responsabilidad. En otras palabras, diríamos, la realidad psicológica del conocimiento, como dato naturalístico, no es requisito indispensable para la atribución a título de dolo. No todo desconocimiento configura un error que excluya el dolo. Y esa distinción entre desconocimiento y error, según Van Weezel, es acogida también, expresamente, por el art. 110 del Código Tributario ${ }^{108}$.

Ahora bien, si comparamos la mención contenida en el art. 456 bis A CP con la que emplea el art. 182 O A, esta última resulta más concordante con la visión normativa del dolo que aquélla. Porque cuando en el Código penal se dice que el autor no haya podido menos que conocer algo, parece aludirse más bien al problema probatorio. En estricto rigor, esa expresión se referiría a que, existiendo indicios que permitan afirmar que el sujeto ha tenido el conocimiento que requiere la norma, no se dará crédito a un alegato de ignorancia sobre el origen de las especies, porque los antecedentes indican que el autor no ha podido menos que conocer. Si se pudiera demostrar, por el contrario, que en realidad el autor carecía del conocimiento exigido, entonces faltaría uno de los presupuestos para la aplicación del tipo.

La referencia a un deber de presumir, en tanto, no queda desvirtuada ni aún en el caso en que existan indicios o, hipotéticamente, prueba fehaciente que demuestre que el sujeto desconocía el origen de la mercancía — conocimiento concebido como representación interna, es decir, como fenómeno psicológico- pues la alusión es directamente normativa. Basta con que exista el deber de conocer, sin importar si se conocía o no.

Esta normativización del dolo no sólo resulta compatible con el principio de culpabilidad, concebido también como parte del sistema normativo del Derecho penal, sino que parece especialmente adecuado en un sector de actividad que, a su vez, está extensamente normativizado. Por una parte, porque existe una compleja regulación aduanera, con diversos mecanismos de control y exigencias de colaboración por parte de quienes pretenden importar o exportar mercancías, para hacer efectivo el sistema, así como obligaciones especiales para ciertos particula-

Esa norma determina los casos en que el desconocimiento excusa, y fuera de ellos, la alegación de desconocimiento respecto de la existencia y contenido de la obligación no tiene como consecuencia la exclusión del dolo del autor, Van Weezel, Delitos tributarios, pp. 45 y 62. Ahora bien, cabe destacar que su interpretación parte de la base de que la teoría de la culpabilidad para el tratamiento del error está en crisis, especialmente por la dificultad teórica y práctica de distinguir entre objeto de valoración —a cuyo conocimiento se referiría el dolo—y valoración del objeto — requerida como elemento de la culpabilidad-, al menos en los tipos que contienen elementos normativos, de lo que se sigue la imposibilidad de distinguir entre error de tipo y error de prohibición pues "la única forma de que la persona distinga qué es relevante en el universo de lo meramente simultáneo radica 
en conocer la valoración jurídica que determina el contexto de relevancia" (p. 36).

Revista Ius et Praxis - año 14 - $\mathrm{n}^{\circ} 183$

Magdalena Ossandon Widow

res. Además, porque los sujetos que cometen esta clase de delitos, con gran frecuencia, ocupan una posición especial en el sistema económico, por la que se les puede atribuir conocimientos especiales. Y por último, porque el delito de receptación aduanera generalmente se incardina dentro de una realidad criminológica compleja, estructurada y organizada, en que la división del trabajo y la atomización de la toma de decisiones dificultan gravemente la prueba de la responsabilidad individual basada en un conocimiento efectivo de todos los elementos del tipo.

Podría criticarse, sin embargo, que esta forma de interpretar la expresión legal, en el fondo, signifique una equiparación entre el dolo y la culpa. Al hacerlo, se estaría sancionando situaciones diversas con penas idénticas, con evidente transgresión del principio de proporcionalidad.

Para rebatir este cuestionamiento hay que partir por reconocer que, efectivamente, una mención como la que analizamos permite equiparar fenómenos psicológicos diversos (conocimiento/desconocimiento). Pero bien interpretada, es decir, como la posibilidad de atribuir el conocimiento necesario para la imputación dolosa más allá del fenómeno psicológico interno real, la cuestión de la proporcionalidad se invierte. Porque lo que el principio de proporcionalidad exige es un equilibrio entre la gravedad del hecho que motiva la reacción punitiva y la intensidad de esta última. Dicho equilibrio no implica que los diversos fenómenos psicológicos deban ser tratados siempre de modo diferente, sino que todo depende de cómo son valorados. Si la actuación del sujeto que desconoce el origen de las mercancías debe ser calificada, en el caso concreto, de la misma gravedad que la de quien obra con pleno conocimiento de esa circunstancia o representándose la posibilidad cierta de que su origen sea delictivo, entonces la intensidad de la pena debe ser la misma, pues en todos esos casos se podría imputar un delito doloso.

Claramente este es sólo el punto de partida, y queda por concretar mejor los criterios que permitían equiparar todas esas situaciones, para distinguir aquellos casos en que el deber de conocer el origen de las especies revista, para el sujeto de que se trate, una especial gravedad que permita la imputación a título de dolo. Pero tratándose de un delito de estas características, que se enmarca en un contexto especial, parece razonable abrirse a esa posibilidad. En este sentido, concordamos con que "al incorporar un genuino componente normativo, la intención definidora del dolo es el fruto de una valoración que en última instancia permitirá deslindar caso por caso los supuestos fronterizos entre el dolo eventual y la imprudencia con arreglo a una práctica (atenta a sus características públicas) propia de la actividad de que se trate"109.

Martínez-Buján Pérez, Derecho penal económico y de la empresa, p. 351. Cfr., también, Vives Antón, Fundamentos del sistema penal, p. 240 y ss.

84 Revista Ius et Praxis - año $14-n^{\circ} 1$

El delito de receptación aduanera y la normativización del dolo

En definitiva, la referencia al deber de presumir que las mercancías han sido o son objeto de un delito aduanero bien puede mantenerse en el tipo de receptación aduanera, como un reconocimiento expreso sobre la posibilidad de asumir un concepto normativo de dolo en nuestro ordenamiento. En cualquier caso, debemos precisar que sería más correcto hablar de un deber de conocer dicho origen (no de presumirlo), pues la mención alude a la atribución del elemento cognitivo del dolo, sea que éste se considere su único elemento o que se estime necesario acreditar, además, el elemento volitivo, según la postura que se adopte a este respecto. 